\title{
Pension reform: Disentangling retirement and savings responses
}

Citation for published version (APA):

Lindeboom, M., \& Montizaan, R. (2018). Pension reform: Disentangling retirement and savings responses.

ROA. ROA Research Memoranda No. 004 https://doi.org/10.26481/umaror.2018004

Document status and date:

Published: 01/01/2018

DOI:

10.26481/umaror.2018004

\section{Please check the document version of this publication:}

- A submitted manuscript is the version of the article upon submission and before peer-review. There can be important differences between the submitted version and the official published version of record.

People interested in the research are advised to contact the author for the final version of the publication, or visit the DOI to the publisher's website.

- The final author version and the galley proof are versions of the publication after peer review.

- The final published version features the final layout of the paper including the volume, issue and page numbers.

Link to publication

\footnotetext{
General rights rights.

- You may freely distribute the URL identifying the publication in the public portal. please follow below link for the End User Agreement:

www.umlib.nl/taverne-license

Take down policy

If you believe that this document breaches copyright please contact us at:

repository@maastrichtuniversity.nl

providing details and we will investigate your claim.
}

Copyright and moral rights for the publications made accessible in the public portal are retained by the authors and/or other copyright owners and it is a condition of accessing publications that users recognise and abide by the legal requirements associated with these

- Users may download and print one copy of any publication from the public portal for the purpose of private study or research.

- You may not further distribute the material or use it for any profit-making activity or commercial gain

If the publication is distributed under the terms of Article $25 \mathrm{fa}$ of the Dutch Copyright Act, indicated by the "Taverne" license above, 


\section{Maastricht University $\$ \mathrm{ROA}$}

\section{Pension reform: Disentangling retirement and}

savings responses

Maarten Lindeboom

Raymond Montizaan

\section{ROA Research Memorandum}

ROA-RM-2018/4

Researchcentrum voor Onderwijs en Arbeidsmarkt | ROA Research Centre for Education and the Labour Market / ROA 


\title{
Pension reform: Disentangling retirement and savings responses
}

\author{
Maarten Lindeboom \\ Raymond Montizaan
}

ROA-RM-2018/4

June 2018

Research Centre for Education and the Labour Market Maastricht University

P.O. Box 616, 6200 MD Maastricht, The Netherlands

$\mathrm{T}+31433883647 \mathrm{~F}+31433884914$

secretary-roa-sbe@maastrichtuniversity.nl www.roa.nl 


\section{Abstract}

\section{Pension reform: Disentangling retirement and savings responses*}

In January 2006, the Dutch government implemented a pension reform that substantially reduced the public pension wealth of workers born in 1950 or later. At the same time, a tax-facilitated savings plan was introduced that substantially reduced the saving costs of all workers, irrespective of birth year. This paper uses linked administrative and survey data to assess the effect of the reform on the savings and retirement expectations and realizations of two virtually identical male cohorts that differ only in treatment status, the treated having been born in 1950 and the controls having been born in 1949. We show that retirement expectations are in line with realizations and that the reform had the intended effect on the labor supply for the larger part of the workers, namely, those without sufficient means to substantially increase private savings to counter the effect of the reform. These workers, who are generally in worse health, have zero substitution rates between private and public wealth. On the other hand, there is a group of mostly high-wage workers who participate in the tax-facilitated Life Course Savings Scheme and who increase private savings to fully counter the impact of the drop in public wealth. A further, unintended side effect of the introduction of the tax-facilitated savings plan is that high wage earners who are not affected by the drop in pension wealth retire even sooner than initially planned.

JEL classification: J26, H55, J14

Keywords: natural experiment, regression discontinuity, retirement, private wealth, public wealth, crowding out, substitution rate

Maarten Lindeboom

VU University Amsterdam

Department of Economics

De Boelelaan 1105

1081 HV Amsterdam

m.lindeboom@vu.nl

and Centre for Health Economics,

Monash University
Raymond Montizaan

Maastricht University

ROA

P.O. Box 616

NL-6200 MD Maastricht

The Netherlands

r.montizaan@maastrichtuniversity.nl

and Netspar

\footnotetext{
We gratefully acknowledge ABP for making the administrative data available. We acknowledge the comments and suggestions of Axel Börsch-Supan; Hans Bloemen; Jose Maria Labeaga; Olivier Marie; Wilbert van der Klaauw; Jon Skinner; Ernesto Villanueva; Jochem Zweerink, seminar participants at the University of Bergen, Norway, University of Alicante, Tor Vergata, Rome, Paris School of Economics, CNRS, Lyon, University of Padova, Ca' Foscari University of Venice, and participants of SOLE 2018, ESPE 2017; EALE 2017; the Uncertainty over the lifecycle, work, health, and pensions workshop, December 2017; the Netspar International pension workshop January 2018 and the NBER-Max Planck workshop, Munich, June 2018.
} 


\section{Introduction}

Most industrialized countries have sophisticated pension systems that provide substantial pension benefits after retirement. These benefits have important effects on employees' intertemporal work and savings choices. However, due to population aging and declining fertility rates, many of these countries have started to implement major pension reforms aimed at increasing the labor supply of older workers. Of importance is whether and to what extent individuals adjust their retirement and savings plans in response to changes in public pension wealth. Is private wealth a good substitute for the mandatory buildup of public pensions and how does this interact with labor supply choices?

This paper looks at the effect of a large permanent and unanticipated change in pension wealth on the private savings decisions and retirement expectations and realizations of Dutch public sector workers born in 1949 and 1950. As of January 2006, the pension rights of those born in 1950 (or later) were substantially reduced, while the pension rights of those born in 1949 (or earlier) were unaffected. The 1949 cohort could retire at age 62 years and three months at $70 \%$ of their gross wages. For the 1950 cohort, the gross replacement rate dropped to $64 \%$ if they wanted to retire at age 62 years and three months or they had to work an additional 13 months to obtain the $70 \%$ rate of their slightly older counterparts. At the same time as the pension reform in 2006, the Dutch government introduced the so-called Life Course Savings Scheme (Levensloopregeling), a tax-facilitated savings program that permits tax-free savings of up to $12 \%$ of annual earnings in a fund that could be used to finance periods of non-employment, such as a sabbatical or early retirement. The introduction of the Life Course Savings Scheme thus enables all workers - those treated by the pension reform as well as those who are unaffected by it - to privately save at lower costs. 
We use linked administrative and survey data over the period 2007-2014 in which we observe the pension rights, individual retirement expectations, decisions to participate in savings programs, and actual retirement choices of public sector workers born in 1949 and 1950. This setup enables us to apply a sharp regression discontinuity design to measure the short-run response (one year after the implementation of the reform) and the longer-run response (up to eight years after the reform).

Our paper is directly relevant to the retirement literature as well as the literature on the substitution between public pension wealth and private savings. Reasoning along the lines of the standard life cycle model, public pension wealth will affect the accumulation of other forms of private savings. In a more general life cycle model with endogenous retirement, the effect of public pension wealth is ambiguous (Feldstein, 1974). Moreover, the rate of substitution between private and public pension wealth depends on a range of factors, such as tax incentives, the relative rate of return to private assets, financial literacy, liquidity constraints, and the myopia of individuals (Alessie et al., 2013). Therefore, the degree of substitution between private and public savings in practice has been the subject of many empirically oriented papers. It is found that private wealth and public pension wealth are not perfect substitutes and that the degree of substitution varies across different studies, between around 20-67\% (e.g., Feldstein, 1974; Feldstein and Pellechio, 1979; Gale, 1998; Bernheim, 2002; Engelhardt \& Kumar. 2011; literature reviewed by Alessie et al., 2013). Attanasio and Bruggiavini (2003) and Attanasio and Rohwedder (2003) further find that the degree of substitution between private and public pension wealth could also depend on the stage of individuals' life cycles. Both studies find that the degree of substitution between private and public wealth increases with age. However, this is likely to differ across older workers too, since the extent to which people can increase private 
savings also depends on whether older people are financially constrained. For these financially constrained workers, adjustments in the labor supply are the only way to counter the drop in public pension wealth.

Labor supply is an important choice variable for older workers confronted with unexpected losses in pension wealth. Workers can theoretically postpone retirement to fully compensate for the loss in pension wealth. This would imply that, in the absence of additional savings, the stabilization of post-retirement income is the main motive and that this is derived at no loss in consumption. This scenario would be consistent with low substitution rates between private and public wealth for older workers. Low substitution rates between private and public pension wealth could also arise when workers choose to not increase savings, stick to the earlier planned retirement age, and thus accept lower post-retirement income. Our study adds to the literature by focusing on a cohort of workers nearing retirement, a group of workers for whom changes in pension wealth require a timely response and reforms can have potentially dramatic effects. As Attanasio and Bruggiavini (2003) and Attanasio and Rohwedder (2003), we expect strong behavioral responses from older workers. However, one can also expect great heterogeneity in the behavioral responses with respect to income and other financial resources. The financially constrained can only adjust the labor supply to compensate for the drop in public pension wealth, whereas those with more financial resources can use these resources to cushion the impact of the drop in public pension wealth.

Our paper is closest to those of Botazzi et al. (2006) and McFall (2011). Botazzi et al. (2006) exploit a series of pension reforms that took place in Italy between 1992 and 1997 to estimate the effects of these reforms on households' retirement expectations and private wealth accumulation. In their analyses, the authors effectively compare the pre-reform behavior of 
cohorts of private sector workers, public sector workers, and self-employed with post-reform behavior. Their findings indicate that workers revised their expectations in accordance with the incentives of the reforms and that there is a substantial offset between private and perceived public pension wealth. McFall (2011) exploits the 2008 stock market crash to test whether retirement plans in the US in 2009 react to a wealth shock in a way that is consistent with a life cycle model with retirement choice. The author finds that, among the 306 workers in the sample who hold private pension wealth, the average wealth loss between July 2008 and June 2009 is associated with an increase in expected retirement of about 2.5 months.

Our study differs from these previous studies in several ways. First, we isolate a single and clear reform that led to a sharp discontinuity design; that is, the assignment rule is simple and clear and implies a strong differential treatment of workers born around January 1, 1950. The cohorts are nearing retirement ages and (as we will show) are well informed about the consequences of the reform. This reduces the noise in observed retirement expectations and savings choices. Second, the drop in pension wealth applied to all workers. McFall (2011) confines the effect of the stock market crash to a specific group of workers, namely, those holding sufficient private assets to influence retirement behavior. ${ }^{2}$ Third, our estimations focus exclusively on workers born in 1949 and 1950, two cohorts that are homogenous with respect to observed characteristics and only differ in their treatment status and that are not subject to other differential policy treatments that can bias our results. The treatment period of Botazzi et al. (2006) is long (1992-2000) and it is therefore not possible to isolate the different impacts of several pension reforms that occurred during this period. Moreover, the authors' sample includes

\footnotetext{
${ }^{2}$ In this paper, wealth is defined as wealth in checking, savings, money market accounts, bonds, mutual funds, stocks, and real estate (excluding primary homes).
} 
a wide age range and they are unable to fully exclude differential treatment in other domains of the social security system, especially for younger workers (those entering the labor market after 1995). Fourth, our paper includes detailed heterogeneity analyses that provide information on the extent to which the substitution rates between private and public wealth and labor supply differ with important worker characteristics. Finally, our results partly confirm the earlier results of Botazzi et al. (2006). Workers revise their expectations in accordance with the incentives provided by the pension reform. However, while these authors find a substantial offset between private and perceived public pension wealth, we show that substitution rates between private and public wealth are generally low but vary greatly with income, education, and health.

Our analyses show that the treatment group immediately adjusts their retirement expectations with about 10.5 months. The drop in pension wealth is equivalent to 13 months of earlier retirement. The difference in expectations between the treated and untreated cohorts remains relatively stable in later years. Our results thus imply that the average treated worker compensates for the drop in pension rights mainly at the expense of leisure in retirement. However, the savings rate (as measured by participation in the tax-facilitated Life Course Savings Scheme) is more than twice the savings rate of the controls. The group that participates in the savings program (16\% of the treated and $7 \%$ of the controls) states that they expect to finance about nine months and 13 months of earlier retirement, for the control and treated cohorts, respectively. For these savings program participants, the difference of four months between the treated and control groups can be interpreted as a pure crowding-out effect induced by the drop in pension wealth, while the nine months of saved earlier retirement of the control group can be interpreted as the impact of the reduction in savings costs (the tax exemption that applies to the Life Course Savings Scheme). Actual retirement, observed eight years after the 
reform in 2014, was in strong accordance with previously expressed retirement expectations. Our findings thus show that individuals are forward looking and that the reform had the intended effect on the labor supply for the larger part of workers, namely, those without sufficient means to substantially increase private savings to counter the effect of the reform. These workers, who generally have lower wages and education levels and are in worse health, thus have low substitution rates between private and public wealth. On the other hand, there is a group of mostly high-wage workers who are less affected by the reform. They participate in the taxfacilitated Life Course Savings Scheme and are therefore able to cushion the impact of the reform by private wealth. There is therefore indeed considerable heterogeneity in the substitution rates between public and private wealth. A further unintended side effect of the introduction of the tax-facilitated savings plan is the decision of high wage earners not affected by the drop in pension wealth to retire sooner than initially planned.

This paper proceeds as follows. Section 2 describes the Dutch pension system and the 2006 reform of the public sector's pension system. Section 3 describes the data and variables used in the analyses. Section 4 presents the results of our empirical analyses. Finally, Section 5 summarizes and discusses the implications of our findings.

\section{The Dutch pension system and the 2006 reform}

\subsection{The Dutch pension system}

The Dutch pension system consists of three pillars. The first pillar is the National Old Age Pension (AOW), which is the basic public old age pension provided by the government to all residents of the Netherlands when they reach the statutory retirement age (65 in 2006). The 
AOW is a pay-as-you-go system in which current payments are financed by income taxes and provides a flat-rate pension benefit related to the net minimum wage.

The second pillar consists of earning-related sector pensions. These pension schemes are predominantly of the defined benefit type and fully funded. Sector pensions are negotiated between unions and employer organizations at the sector or firm level and are usually set forth in collective agreements. Participation is mandatory for individual workers, ensuring that each worker is covered by the sector pension. The Pensions and Savings Act (Pensioen en Spaarfondsenwet) until 2007 and the Pensions Act from 2007 onward (Pensioenwet) dictate that the administration of the sector pension schemes in the second pillar is delegated to pension funds to which both employers and employees must contribute. The sector pension schemes allow workers to retire before the statutory retirement age of the public pension. Until 2006, contributions to sectoral early retirement schemes were tax deductible, which substantially increased their financial attractiveness. This tax advantage amounted to about $25 \%$ of the net early retirement allowance, partly because of the progressive tax system (Euwals et al., 2006). Typically, contributions to the sector pension schemes were such that, in 2006, a public sector employee who had served 40 years in the public sector could retire at the age of 62 and three months at a gross replacement rate of $70 \%$ of average yearly earnings since 2004 . Therefore, early retirement facilitated by the preferential tax treatment of sector pension schemes was the social norm in the Netherlands. Approximately $80 \%$ of all workers retired at the age of 62 or younger before 2006 and only 6\% retired at the age of 65 (Statistics Netherlands, 2009).

The third pillar finally consists of all voluntarily built-up savings supplementary to the public and sector pensions. These are offered by private insurance companies and typically yield annuity payments at retirement age. Due to the well-established public and sector pension 
systems, the third pillar is less well developed in the Netherlands. It provides only $5 \%$ of the retirement income that is provided by the second pillar of the pension system (Bovenberg \& Gradus, 2015).

\subsection{The 2006 reform of the pension system}

In 2006, the government abolished the favorable tax deductibility of contributions to early retirement schemes that are part of the second pillar of the Dutch pension system for all employees born in 1950 or later. In response to the abolishment of the favorable tax treatment, the government and unions in the public sector negotiated a new pension scheme in the summer of 2005 that became effective on January 1, 2006, for workers born in 1950 or later and for those born before 1950 who had not worked continuously in the public sector since April 1, 1997. This new scheme, called the ABP Flexible Pension Scheme, is administered by the public sector's pension fund (Algemeen Burgelijk Pensioenfonds, or ABP). In the Netherlands, as in other countries, there has been an ongoing debate about the sustainability of the pension system and the need for reform. Therefore, the announcement of a reform was not entirely unexpected. What was unexpected, however, was the speed at which the reform was implemented, as well as the strong differential treatment of workers born around January 1, 1950, which came as a surprise when it was announced on July 5, 2005.

This new ABP Flexible Pension Scheme involves (i) a drop in pension benefits, (ii) a small increase in pension contribution payments to partly account for the drop in pension benefits resulting from (i), and (iii) stronger incentives to continue working, generated by penalties on pension income when retiring before the statutory pension age (AOW) and by supplements for later retirement. Furthermore, the eligibility age for early pension benefits has 
been increased to 60 years and workers can now decide to continue working until their 70 th birthday. $^{3}$

Workers born before 1950 remained entitled to the old, more generous early retirement scheme if they had worked continuously in the public sector since April 1, 1997. This means that such workers could still retire early, between ages 55 and 65. For those born before 1950, retirement at age 62 years and three months yields a pension benefit with a gross replacement rate of $70 \%$ of average yearly earnings since 2004 (equivalent to an annual benefit of $€ 31,500$ for the median worker in our sample). Due to the reform, a typical employee born in 1950 or later with 40 years of tenure would obtain a gross replacement rate of $64 \%$ when retiring at the age of 62 years and three months (equivalent to an annual benefit of $€ 28,500$ for the median worker in our sample). To attain a replacement rate of $70 \%$, these workers would have to postpone retirement by 13 months.

At the time of the pension reform in 2006, the Dutch government also introduced the Life Course Savings Scheme (Levensloopregeling), a tax-facilitated savings program. The program, open to all workers, irrespective of their year of birth, permits tax-free savings of up to $12 \%$ of annual earnings in a fund that can be used to finance periods of non-employment, such as a sabbatical or early retirement. ${ }^{4}$ The savings accounts are held at insurance companies, banks, or the subsidiary companies of pension funds. Various life course saving products are offered. Life Course Saving accounts can take the form of traditional savings, an investment account, or a mix of both products. All workers are allowed to save up to a maximum of $210 \%$ of their annual earnings in the fund. At a gross replacement rate of $70 \%$, this would cover three years of early retirement. Those born in the years 1950 through 1954 and who therefore had less time to save

\footnotetext{
${ }^{3}$ It is not mandatory for employers to keep employees when they become eligible for the AOW. Employers are allowed to discharge such employees when they reach the age of eligibility.

${ }^{4}$ Employers must allow their employees to take leave financed by the Life Course Savings program.
} 
$210 \%$ than older cohorts were allowed to save more than $12 \%$ of their annual earnings, as long as the cumulative maximum does not exceed $210 \%$ of annual earnings. It must be noted, however, that workers of the 1950 cohort must save approximately $16 \%$ of their annual earnings for six years to finance early retirement at age 62 (rather than retirement at age 63 and one month). It is likely that only a very small fraction of such workers is willing or capable of saving such a large share of their earnings each year before retirement. Nevertheless, we expect workers treated by the reform who do not wish to change their retirement plans but plan to repair part of their pension wealth to invest more in these savings, since, due to the tax exemption, it is the cheapest saving product in the Netherlands.

Besides the introduction of the ABP Flexible Pension Scheme, no other institutional changes differentially affect the 1949 and 1950 cohorts in 2006 . We can therefore apply a sharp regression discontinuity design. For the internal validity of our research design, it is crucial that workers born in 1950 are aware of the consequences of the new pension system for their individual situation. After the announcement of the reform in the summer of 2005, the pension fund ABP launched a massive campaign to inform its clients about the new pension and Life Course Savings Scheme and explain its financial implications. In a special newsletter, unions, employer organizations, and the ABP jointly explained the ABP Flexible Pension Scheme. Furthermore, all 1.2 million ABP members received a personalized letter about the core characteristics of the new scheme, along with a complete electronic service package for public service employers. Therefore, one can assume that, on January 1, 2006, most public sector employees born after 1949 and their employers were indeed made aware of the exogenous shock in their pension rights. Of course, this must be verified empirically, which we do when discussing the descriptive analyses in Section 3. 


\section{Data collection and descriptive analyses}

\subsection{Data collection}

We use survey data that we match to administrative data for a panel of male full-time employees in the public sector who were born in 1949 or $1950 .{ }^{5,6}$ The administrative data are available from 2006 until 2014 and contain detailed information on individuals' accrued pension rights at the $\mathrm{ABP}$, retirement status, pension benefits, annual wage, number of contractual working hours, tenure in the public sector, and employment subsector.

The panel survey data was started one year after the new pension system was established in 2007 and was repeated annually until 2012. The data in the first wave in 2007 were gathered in two stages. In the first stage, all 27,719 male public sector workers in the Netherlands who were born in 1949 or 1950 were invited in January 2007 to participate in our Internet survey by requesting their e-mail addresses. The invitation letter, sent by surface mail, included general information about the social usefulness of the survey but did not disclose information about the research question or the nature of our research strategy. We did not inform potential participants that the invitation letter was sent only to public sector employees born in 1949 and 1950. The letter also explicitly assured confidentiality. In the second stage, the 11,458 workers who sent their e-mail address received, in March 2007, an e-mail with a link to the survey. References to the nature of our research question and research strategy were also carefully avoided in the survey.

In total, 8,516 individuals completed the questionnaire in 2007 . The response rates to the surveys for the two birth cohorts were virtually identical in $2007,30.5 \%$ and $31.0 \%$ for the

\footnotetext{
${ }^{5}$ De Grip et al. (2012) and Montizaan et al. (2009, 2011, 2016) exploit the same data set to estimate the impact of retrenchment in pension rights on short-term workers' health and well-being and human capital investments.

${ }^{6}$ The survey and administrative data are available only for these two specific birth cohorts. We focus on male employees because, in the Netherlands, in this birth cohort, male workers are usually the main family wage earner and only a small, selective fraction of women in this cohort is are still working at the age of 57 or 58.
} 
treated and controls, respectively (see also De Grip et al., 2012, who use the same data). Our analyses are restricted to full-time employees who worked continuously in the public sector since 1997 until 2006 and did not work in strenuous jobs (e.g., firefighters, police officers). ${ }^{7}$ For these workers, the pension reform is clear and simple, since age is the only criterion that determines whether a worker is eligible for the restricted or the more generous retirement scheme, guaranteeing the internal validity of the regression discontinuity design. After these selections, the final estimation sample in 2007 consists of 6,702 men, 3,468 of whom were born in 1950 and 3,234 in 1949. The survey was repeated in March of every year until 2012. The responses numbered 4,142 in $2008,6,048$ in $2009,5,600$ in 2010 , and 4,020 in 2011. The increase in the number of responses in 2009 is due to a renewed invitation to participate in the Internet survey. This invitation was sent to counter panel attrition. In Tables B1-B4 in Appendix B, we examine whether sample attrition was selective with respect to the treatment. These tables show that the response rates do not differ between workers born in 1949 and 1950 and that this result does not change when we use additional sample selection criteria. The tables also show that attrition in later waves (i.e., after 2007) is unrelated to the treatment.

\subsection{Measuring retirement expectations and private savings behavior}

Our main interest lies in investigating how the change in the pension system affects the retirement expectations and realizations and saving decisions of public sector workers. To elicit retirement expectations before the reform took place, we asked respondents in 2007 the following survey question: “At what age did you expect to retire five years ago?" To measure the development in retirement preferences and expectations after the reform, we asked two questions

\footnotetext{
${ }^{7}$ Firefighters and ambulance and police personnel still have other retirement schemes that allow early retirement between the ages of 55 and 62 with a replacement rate of at least $70 \%$.
} 
in the survey annually: (1) “At what age do you expect to definitively stop working?" and (2) "What would your pension benefit be as a percentage of your net wage income if you retire at the age of $62 ? "$

There is an extensive literature on retirement expectations and the general consensus seems to be that retirement expectations measured this way accurately match realizations (Bernheim, 1989, 2009; Dwyer \& Hu, 2000; Chan \& Stevens, 2004; Benítez-Silva \& Dwyer, 2005). In this paper, we observe expectations for eight years as well as actual retirement realizations until 2014 and can therefore examine, in addition to behavioral response to the policy reform, how well expectations match retirement realizations.

Our survey annually includes several questions on pension savings that enable us to analyze such behavioral responses. First, the survey includes a question on whether the respondent participates in the Life Course Savings Scheme. Those who do are also asked how many months of earlier retirement they plan to finance out of this Life Course Savings Scheme (only in the 2009 wave). This direct question will enable us to also disentangle the underlying mechanisms driving the adjustments in retirement planning. We return to this later in Section 4. Second, the survey asks whether respondents made additional savings arrangements for their pension in the past year and how many alternative sources of (pension) wealth they can access. These alternative pension products include (1) pensions built up at pension funds other than $\mathrm{ABP}$, (2) life annuities, (3) life insurance, (4) savings in excess of $€ 15,000$, (5) investments, (6) inheritance, and (7) other pension insurance products. Moreover, the survey asks whether the respondents has a partner with his or her own income, has a partner with his or her own pension, and whether workers have positive net housing wealth (the value of the house minus the 
mortgage). This enables us to control not only for individual wealth but also for the major components of household wealth.

\subsection{Descriptive analyses: Comparing the treated and control cohorts}

Since our empirical analyses exploit the sharp discontinuity in pension treatment induced by the natural experiment, it is of crucial importance for the internal validity of our natural experimental approach that (1) the individuals in the treatment and control groups are sufficiently similar in order to ascribe the difference in retirement expectations, realizations, and savings behavior between the treatment and control groups to the pension reform and (2) the reform was well understood and actually created a sharp discontinuity in expectations.

First, as already mentioned, while attrition was substantial, the survey participation rates of both cohorts are very similar for each year of the panel survey (see Tables B1 and B2 of Appendix B). Second, Table 1 shows descriptive statistics for the treatment and control groups for the 2007 wave. While the first two columns show the respective means, the last column tests whether the differences are significant. Table 1 confirms that job and personal characteristics and the sector in which employees are employed are indeed similar across both cohorts. We also performed this test for the subsequent years 2008-2012 and find no significant differences in observables between the treated and untreated respondents (results available upon request).

Concerning personal characteristics, we observe that approximately $67 \%$ of public sector workers are highly educated, $90 \%$ are married, and they are, on average, in good health. The more highly educated are overrepresented in the public sector, which is confirmed in other (Dutch) data sets. Most respondents are employed in the government (47\%) and education (41\%) sectors and work full time. 
Among the set of wealth variables, one is significantly different at conventional levels between the control and treatment groups: the response to the question whether individuals participated in the tax-facilitated Life Course Savings Scheme. Only 6.4\% of the 1949 cohort participated in this Life Course Savings Scheme, whereas, for the 1950 cohort, this fraction is more than two times higher (about 16\%). Because this tax-facilitated program was introduced at the same time as the pension reform, the participation rates in the Life Course Savings Scheme for the treated can be seen as a direct response to a reduction in savings costs plus the drop in pension wealth. For the controls, it is a direct response to a reduction in savings cost.

\subsection{The respondents understood the consequences of the reform}

As mentioned at the end of Section 2, the consequences of the reform were communicated extensively to the affected cohorts. Moreover, employees receive annually a detailed overview of their pension rights that shows them exactly the pension benefits they would receive if they were to retire at different ages. The sample means confirm that the respondents had a good overview of their pension and the consequences of the reform. Respondents born in 1949 expected, on average, a pension benefit at a net replacement rate of $72 \%$ if they had to retire at age 62 , while employees born in 1950 anticipated a replacement rate of $66 \%$ at that age. This difference is statistically significant and remarkably close to the difference in the actual (gross) replacement rates of $70 \%$ and $64 \%$ for the 1949 and 1950 cohorts, respectively. Figure 1 depicts this graphically, with each dot representing the average expected pension benefit for individuals born in a specific birth month. The figure confirms once more that the respondents understood the consequences of the reform, with a strong discontinuity in the expected pension benefit around 
the threshold date of January 1, 1950. The same figure for later years displays a similar pattern (see Figure A1 of Appendix A).

The average response to the retrospective survey question on the respondents' expected retirement age five years ago (measured in 2007) does not differ significantly between the treated and control groups. This also becomes clear in Figure 2, a graphical representation of the expected retirement age before the reform (in 2002) for workers born in 1949 and 1950. The figure shows no clear break around the threshold age. ${ }^{8}$ Things look very different for the expected retirement age one year after the reform: those born in 1949 expected, on average, to retire at age 62 years and eight months, while those born in 1950 expected to retire at age 63 years and six months. Figure 3 graphically shows this discontinuity. Note that the expected age of retirement reflects both changes in the pension system as well as the respondent's behavioral response to this reform. The fact that the difference in expected retirement ages between the treated and controls is close to the 13 months that people must work in addition is surprising, in that respect, and suggests that most workers are not willing to sacrifice much current and future consumption for previously planned leisure. Note that, in 2007, the respondents were 57 or 58 and their expectations could change over time. Below we examine this issue more closely.

\section{Empirical implementation and results}

\subsection{Empirical implementation}

A permanent change in public pension wealth forces workers to reconsider previously made retirement and savings decision. Indeed, in the extended life cycle model of Feldstein (1974), savings and retirement decisions are jointly determined and (exogenous) changes in public

\footnotetext{
${ }^{8}$ We additionally performed a Kolmogorov-Smirnov test of the equality of the distribution functions. The test indicates significant differences between the distributions of both cohorts.
} 
pension wealth induce a "wealth replacement effect" and a "retirement effect". In our context we can write a quasi-reduced form equation for adjustments in retirement expectations as a function of the treatment as:

$$
d E R_{i t}=E R_{i t}-E R_{i 2002}=\alpha_{0}+\alpha_{1} I(1950)_{i}+\alpha_{2} B_{i}+\alpha_{3} B_{i}^{2}+\alpha_{4} X_{i t}+\varepsilon_{i t}
$$

where $E R_{i t}$ is the expected retirement age in year $t, I(1950)$ is an indicator for the 1950 cohort, $B$ stands for the running variable birth date (expressed in days, normalized to zero on December 31, 1949, and divided by 100), and $X$ is a set of observed individual characteristics, some of which are from the survey and some from the administrative database. ${ }^{9}$ The previous section confirmed that, prior to the reform, no differences in retirement expectations existed; that is, the expectations in 2002for both cohorts were identical (see Figure 2 and Table A2 of Appendix A). Therefore, we may equally well estimate (1) in levels of $E R_{i t}$. We perform both estimations and show that the results are very similar. In the next sections, we consider both short-run effects $(t=$ 2007) and longer-run effects $t=2008, \ldots, 2011$.

The reform differentially affected the two cohorts and entailed two changes: (i) a reduction in public pension wealth that applied only the 1950 cohort and (ii) a tax-facilitated savings program that effectively changed the return of additional savings due to lower costs of savings. The latter change applied to both cohorts. The treatment effect (parameter $\alpha_{1}$ ) is therefore the compound effect of the direct effect of the change in pension wealth on the labor supply and the indirect effect of additional savings. This indirect savings effect is a direct

\footnotetext{
${ }^{9}$ Note that, strictly speaking, a regression discontinuity design also requires differential age $(B)$ trends for the treated and control groups. Additional regressions with differential age trends do not change the results at all. Indeed, Figure 2 shows no age trend effects.
} 
measure of the degree of substitution between public and private wealth and consists of an effect caused by the drop in pension wealth plus an effect caused by lower savings costs.

$$
\begin{aligned}
& \text { Similarly, for savings } S \text {, we can write } \\
& S_{i t}=\beta_{0}+\beta_{1} I(1950)_{i}+\beta_{2} B_{i}+\beta_{3} B_{i}^{2}+\beta_{4} X_{i t}+\varepsilon_{i t}
\end{aligned}
$$

Rather than the actual amount of savings, we observe whether an individual has saved in various ways to finance retirement (see Section 3). For $S$, we distinguish whether an individual participated in the Life Course Savings Scheme and whether they made (other) additional savings in the past years to supplement their pension. ${ }^{10}$ Note that the Life Course Savings Scheme introduced at the time of the reform was accessible to both cohorts and, therefore, $\beta_{1}$ measures the additional effect for the treated (1950) cohort. The variables $S$ and $d E R$ are jointly determined and, therefore, besides our (single) instrument, more information is required to tease out the direct and indirect effects contained in $\alpha_{1}$ (and $\beta_{1}$ ). Fortunately, the 2009 survey also contains a question about the number of months the participants in the Life Course Savings Scheme expected to finance from this program. Via this question, we can obtain an estimate of the indirect savings effect induced by the reform. We will return to this issue below.

\subsection{Short-run effects of the reform}

\subsubsection{Retirement expectations one year after the reform}

The first two columns of Table 2 provide the ordinary least squares (OLS) results of equation (1) for 2007. The treatment dummy refers to the average treatment effect of the reform for the cohort born in 1950. From a comparison between Columns 1 and 2, one can conclude that the addition

\footnotetext{
${ }^{10}$ We observe a range of other measures, such as whether the respondents have positive net housing wealth and whether their partner has an income (see Section 3). These are unlikely to be a direct response to the pension reform and therefore only used in a later section, when we look at heterogeneous effects.
} 
of controls does not alter the parameter estimate of interest. This result once more confirms that the treatment and control groups, besides birth year, are very similar. The table also includes the regression where the left-hand side of (1) is replaced by the retirement expectation in 2007 (Columns 3 and 4). A priori, one would not expect to find differences in the effect of the treatment dummy. After all, in Section 3 (Table 1), we already note that retirement expectations five years ago (2002) were virtually identical for the two cohorts. Indeed, the coefficients of the treatment dummy are very similar.

The coefficient of interest $\left(\alpha_{1}\right)$ indicates that, in the short run, workers affected by the reform expect to work about 0.88 years (about 10.5 months) longer. Since the drop in pension wealth is equivalent to 13 months of earlier retirement, our results imply that the average treated worker compensates for the drop in pension rights mainly at the expense of leisure in retirement (and only marginally decreases pre- or post-retirement consumption, i.e., the remaining 2.5 months). It is important to note (see also Section 4.1) that this is the total average treatment effect on the treated and it consists of two opposing forces: the adjustment in retirement years (direct effect) when no additional savings are made plus the effect of additional savings in the Life Course Savings Scheme to compensate for the drop in pension rights (indirect effect).

Figure 3 confirms that the size of the effect of the reform is a little less than one additional year labor supply. However, a comparison with Figure 2 also shows that the controls (1949 cohort) adjusted their expectations slightly upward. This could be caused by control's anticipation of further reforms that could also affect their pension wealth. The regression results in Column 2 show that the higher educated and those with higher incomes retire sooner than the others. 


\subsubsection{Savings one year after the reform}

Table 3 provides the results for two of our savings measures that we expect to be responsive to the reform: whether individuals participated in the tax-facilitated Life Course Savings Scheme (Columns 1 and 2) and whether they had extra pension savings over and above the ABP pension in the previous year (Columns 3 and 4). Figure 4 gives a graphical representation. Columns 1 and 2 indicate that the probability of participating in the Life Course Savings Scheme is about 8 percentage points higher for the treated cohort. This effect is virtually unchanged when we add regressors. Of these regressors, individuals' wages and the number of years they contributed to the pension fund have a notable and significant effect. Taking the mean of these variables into account (see Table 1), we can conclude that the wage effect is by far the dominant factor in explaining participation in the Life Course Savings Scheme. ${ }^{11}$ Apparently, the wage effect reflects the ability to save. Columns 3 and 4 show no significant treatment effects on extra pension savings. ${ }^{12}$ A further look at the other coefficients in Column 4 reveals that the effect of the number of years of contribution to the pension system has a sizeable effect, its coefficient being more than three times that in Column 2. This result suggests that the number of years of contribution to the pension fund is likely to reflect the need to save and that these savings already existed prior to the reform. In sum, the drop in pension wealth and the reduction in savings costs primarily affected savings via the Life Course Savings Scheme. Wages have a strong independent effect (irrespective of treatment status) on the decision to participate in the taxexempt Life Course Savings Scheme. The number of years of contribution to the pension fund

\footnotetext{
${ }^{11}$ A one-standard-deviation change in the logarithm of wages (mean 10.7) results in a change of 0.025 (2.5 percentage points). For the difference between the top (11.10) and bottom deciles (9.98), this results in an effect of $10 \%$.

${ }^{12}$ We also looked at other forms of savings in the data. None of these regressions resulted in significant treatment effects.
} 
has an additional, independent effect on both participation in the Life Course Savings Scheme and additional savings to supplement pension income.

The Life Course Savings Scheme, introduced at the same time as the pension reform, facilitated savings at lower costs for both the treated and control groups. The treated were thus confronted with a drop in their pension wealth and an opportunity to save at lower cost. The controls were only affected by the latter change in the system. Observed changes in the (Life Course Savings Scheme) savings of the controls are therefore most likely in response to the reduction in the cost of savings, while observed changes in the savings of the treated are the sum of the savings increase induced by the drop in public pension wealth and the savings induced by the lower cost of savings. For the participants in the Life Course Savings Scheme, the 2009 survey also includes a question about the number of months they planned to finance from this savings account. Figure 5 presents this data graphically. The smoothed line indicates that those born in 1949 planned to finance nine months' earlier retirement from their savings account. The average for the affected (1950) cohort is about four months more. This result is confirmed in Table 4. These four months can thus be interpreted as a pure substitution effect between private and public pension wealth, that is, a pure crowding out effect due to the drop in public pension wealth. The figure also suggests that treated workers participating in the Life Course Savings Scheme planned to fully counter the intended effect of the reform on retirement (13 months later retirement). About four months can be ascribed to the drop in pension wealth induced by the reform and about nine months due to reduced savings costs (tax exemption).

The results of Table 2 indicate that, on average, the treated work about 10.5 months longer $(0.879 * 12=10.55$ months $)$. Of the treated sample, about $16 \%$ of those who participated in the Life Course Savings Scheme intended not to work 13 months longer (see Figure 5) but, 
rather, stick to the previously set retirement age. This implies that the treated who did not participate in the program expected to work $10.55 / 0.84=12.6$ months longer, that is, almost completely the intended effect of the reform. Hence, these workers were not willing to sacrifice future pension income for more leisure years in retirement or to sacrifice their current income but predominantly countered the drop in public pension wealth by sacrificing leisure (retirement years). The results of Table 3 indicate that wages are the dominant factor in explaining the decision to participate in the Life Course Savings Scheme. In light of the above, this could imply that primarily lower-wage workers are induced to postpone retirement. What is problematic, however, is that these workers generally also have worse health. ${ }^{13}$ Indeed, a regression of the logarithm of wages on sickness and a set of other controls shows a significant negative association between wages and sickness (results available upon request). This finding suggests that financial constraints rather than a low disutility of work are at play in the decision to postpone retirement.

\subsection{Longer-run effects}

\subsubsection{Developments in retirement expectations (2008-2011)}

The above results show strong initial responses to the reform on retirement. Of interest is whether retirement expectations change in the longer run and, ultimately, whether expectations match realizations. Starting with expectations in the longer run, we estimate model (1) for the years 2008 to 2011. It is important to note that our longer-run analyses focus on respondents who responded at the start of the panel, because we wish to follow the expectations of the respondents

\footnotetext{
${ }^{13}$ See also the vast literature on the strong association between socioeconomic status and health (e.g., Banks et al., 2006).
} 
in our original sample over time. We therefore do not use the additional response due to the renewed invitation to participate in the Internet survey in later years. ${ }^{14}$

Note also that those born in 1949 (controls) will have turned 62 in 2012, the age at which this cohort could retire with a $70 \%$ replacement rate. This cohort could also retire at earlier ages with lower replacement rates. This holds also for the 1950 cohort, who had to be 63 (in 2013) to receive a 70\% replacement rate. In March 2011 (when the survey was held), 13.8\% of the 1949 cohort and $3.7 \%$ of the 1950 cohort had retired. After 2011, these fractions rapidly increased (notably for the 1949 cohort; we return to examine actual retirement patterns in the next subsection). We therefore restrict ourselves to retirement expectations in the period 2008-2011.

Model (1) could be estimated for the expected retirement age (ERit) or the change in the expected age of retirement relative to $2002\left(d E R i t=E R i t-E R i_{2002}\right)$. Below, we discuss the results for the change in the expected retirement age, dERit, $t=2007, \ldots, 2011$. Table A2 in Appendix A reports the result for the retirement expectation levels, that is, ERit, $t=2007, \ldots$, 2011. The results of these regressions are very similar to the results discussed below.

The first column of Table 5 repeats the results of the Column 1 of Table 2, while the other columns show the results for later years. The most important result is that the longer-run treatment effects are not much different from the short-run effect. Therefore, the readjustments took place shortly after the reform and the workers stuck to these in later years. The consistence in the treatment effects can most likely be explained due to the fact we are analyzing the behavior of older workers confronted with substantial changes in pension wealth only a few years prior to their initially planned retirement. The situation could be different for younger cohorts. The treatment indicator is somewhat smaller for 2009. For 2010 and 2011, the effects

\footnotetext{
${ }^{14} \mathrm{We}$ also conducted our longer-run analyses on the dynamics in retirement expectations $\left(E R_{i t}\right)$ using these additional responses (results available upon request). The results did not change substantially.
} 
are again closer to expectations in 2007. Figure 6 (retirement expectations) and Figure A1 (retirement benefit expectations) provide more information that could explain the patterns. Figure 6 shows that the smaller effect in 2009 is primarily due to the higher expected retirement ages of the controls (born in 1949). In 2009, the consequences of the financial crises for pensions became clearer and the controls might have expected that, sooner or later, these would also affect their pension wealth and eligibility conditions for early retirement. ${ }^{15}$ This situation is also reflected in the retirement benefit expectations for 2009 (Figure A1). The controls (and the treated) also adjusted their benefit expectations downward. For the later years (2010 and 2011), the expectations of both cohorts rose again, coming closer to the 0.8 years in 2007 . This could be due to the very early retirement of some workers, increasing the average of those remaining in the sample. Alternatively, in the aftermath of the financial crises, both cohorts could have adjusted their retirement expectations upward and benefits expectations downward. Indeed, the plots in Figure A1 show substantially lower benefit expectations for both cohorts. While the idea of a more pessimistic outlook could be a plausible explanation, one still cannot dismiss the idea that actual retirement could influence the patterns. After all, those with relatively high benefit levels could have decided to retire earlier, reducing the average expected benefit levels in the remaining sample.

\subsubsection{Retirement realizations}

The survey data are linked to administrative data containing information on actual retirement up to March 2014, which implies that those born in the first months of 1949 have turned 65, the statutory retirement age. Therefore, besides differences in pension rights and eligibility

\footnotetext{
${ }^{15}$ The 2008 recession led to substantial deficits in the ABP fund, which led to temporary cutbacks in pension benefits and withholds indexation. This was communicated to the workers and displayed in the media.
} 
conditions, the pure age effect will also lead to substantially higher retirement ages for the controls. Figure 7 confirms this effect. The retirement rates of the 1949 cohort range from about $70 \%$ to more than $90 \%$ for those born in the first quarter of the year. In contrast, the retirement rates of the 1950 cohort are 40-50 percentage points lower. The regression results in Table 6 show, controlling for age, that the pure treatment effect is about 23 percentage points. This finding indicates that the reform did what it was intended to do: postpone retirement. Table 7 shows the retirement age distribution for the two cohorts. At each age, the retirement rates of the controls are much higher, but also note that the retirement rates of the treated seems to lag by about one year. More specifically, the fraction of treated retired at age 61 is about the same as the retirement rate of the controls at age 60 . The same holds for the other ages of the treated, with an exception for age 64. We only observe actual retirement up to March 1, 2014, implying that, in March 2014, the treated born in the first quarter was 64 while the rest would turn 64 in the course of the year. Each year, the retirement dates are mostly concentrated at the start of the year and after the summer vacation. Therefore, it is important to realize that, for the treated, the fraction of 64-year-old retirees could be lower than the comparable fraction of 64-year-olds among the controls, whose numbers are based on the entire calendar year (2013). Nevertheless, to conclude, the results in Table 7 confirm that the reform postponed retirement by about one year, as intended.

The above results again suggest that those affected by the reform chose to work longer rather than sacrifice pension income for earlier retirement. In earlier sections, we also saw that about $16 \%$ of the affected cohort chose to participate in the tax-facilitated Life Course Savings Scheme and that these workers intended to fully counter the effect of the reform. Unfortunately, those participating in the Life Course Savings Scheme were not considered as retired when they 
took a self-financed leave before the actual date of retirement. We therefore cannot check this with the administrative data, but it is conceivable that a fraction of the workers observed in the data as retiring later could, in fact, have stopped working earlier.

The effectiveness of the program in postponing retirement could have to do with how the program was implemented. It was announced late in the game for the workers in our sample and implemented only a few months after its announcement. Consequently, not all workers may have gathered sufficient means to fully counter the reform with additional savings, either because they were not in a (financial) position to save sufficiently or because they were not willing to sacrifice current consumption. Indeed, the savings regressions (see the discussion involving Table 3) show income as an important factor in participation in the Life Course Savings Scheme and that the participants fully countered the drop in public pension wealth with additional savings. Consequently, the behavioral response to the reform is likely to differ across subgroups, notably those with higher wages and other sources of wealth. We address this issue below.

\subsection{Heterogeneous effects}

We run separate OLS regressions on the different subsamples to examine heterogeneous responses to the reform. For each subsample, we look at short-term (2007) retirement expectations, participation in the Life Course Savings Scheme, and retirement realizations in March 2014. We look at two sets of variables that are related to retirement planning and savings behavior: the set of wage, education, health, and wealth variables (A) and a set of individual risk aversion and financial decision making variables (B).

The definitions of the set of wage, education, health, and wealth variables are selfexplanatory and the inclusion of heterogeneity analyses with these variables can be easily 
justified. One can expect that workers with higher wages and more education overall have accumulated more private wealth and therefore have more opportunities to maintain current and post-retirement consumption levels while keeping leisure years in retirement close to those initially planned (i.e., before the reform). The costs of prolonged work are higher for those in poor health and one might therefore, at first instance, expect those in poor health to retire earlier, that is, have lower treatment effects. Note, however, that the reform could have impacted health (for such findings on mental health, see DeGrip et al., 2012) and, therefore, the results could at best be interpreted as an association. Previous research, furthermore, shows that the retirement decisions of members within families are related (e.g., Gustman and Steinmeier, 2004) and that the financial impact of the pension reform is larger for workers who have to provide for a family and whose partner does not contribute to the household (pension) income (Bloemen et al., 2015). We therefore also run separate regressions for whether the respondents indicated that they had a partner who would also receive a pension. ${ }^{16}$

The set of variables related to financial decision making variables consists of risk aversion, financial risk aversion, and the self-reported capability to make decisions in complex situations. Risk attitude plays an important role in intertemporal decision making under uncertainty and could, therefore, also affect the degree of substitution between private and public pension wealth. A lack of the respondents' ability to make decisions in complex situations is expected to lead to procrastination and lower levels of wealth accumulation (Banks et al., 2010).

\footnotetext{
${ }^{14} \mathrm{We}$ also ran regressions for the other income and savings variables (see Table 1). These regressions did not provide additional insights. Moreover, we ran several other regressions for the partner's treatment status, the partner's wage income, and the number of children. We found that the retirement expectations, actual retirement behavior, and savings decisions have no impact of the size of the treatment effect (results available on request). This is not surprising, because most female partners in this age cohort have part-time jobs and little pension wealth of their own.
} 
A measure of risk aversion is derived from the responses to the survey question, "How do you see yourself: Are you, generally, a person who takes risks or do you try to avoid risks? Please self-grade your choice (ranging between 0 (extremely risk averse) and 10 (extremely willing to take risks))." We reverse the scale of the answers and consider people to have low risk aversion when they give a grade above five (upper quartile). ${ }^{17}$ The financial decision making variable is derived from the same question, adapted to financial decision making. The capability to make difficult decisions is measured by the survey question, "To what extent are you generally able to make a financial decision, even when the decisions are of a complex nature? Please self-grade your choice (ranging between 0 (extremely unable) and 10 ((extremely able)))." We construct an indicator for the bottom quartile, that is, those less able to make a decision in such situations. The level of item non-response is quite high for these variables.

The top panel of Table 8 shows the results for short-run retirement expectations, the middle panel the results for participation in the Life Course Savings Scheme, and the bottom panel the retirement status in March 2014. The p-values in the penultimate row of each panel are based on the coefficient of the treatment dummy and the heterogeneity variable in fully interacted models. Below, we briefly discuss the main findings.

For changes in retirement expectations (top panel of Table 8), we find a stronger treatment effect for the risk averse, meaning that these workers generally extended their working life much longer than the others did. For none of the other variables (wage, education, partner's pension, and health) do we find differential treatment effects. Note that this does not imply that these variables play no role in expectation formation (cf., see the coefficients for wages and education in Table 2). The second panel of Table 8 shows the results for participation in the Life Course Savings Scheme. Again, the response to the drop in pension wealth does not differ by

\footnotetext{
${ }^{17}$ In the literature, this question has been used extensively to elicit risk preferences (e.g., Dohmen et al., 2011).
} 
respondent income, education, partner's pension, or health. We do, however, observe sizeable and significant differences between different subgroups related to financial decision making variables. Basically, the risk averse and those with low capabilities of making difficult decisions do not respond to the drop in pension wealth. The results for risk aversion may seem counterintuitive at first. However, it should be noted that the Life Course Savings account is not like a traditional savings account but often involves a mix between traditional savings and investments in stocks or bonds and thus involves more risk than traditional saving products. The finding for decision making in complex situations could be due to the fact that respondents who have difficulties making decisions in financially complex situations often procrastinate in such situations and accumulate less wealth (Banks et al., 2010). We also run a simple regression that relates (financial) risk aversion to wages and income. These regressions (results available upon request) show that risk aversion is negatively associated with wages and education.

Finally, for actual retirement status in 2014, we find strong differential effects for wages, education, and health. ${ }^{18}$ The treatment effects of those with higher wages, more education, and fewer sickness days are substantially lower than the effects of their lower-wage, less educated, and sicker counterparts. We find no effects for the financial decision making variables, while they appear to be important for participation in the Life Course Savings Scheme. It is important to note that the treated who participate in the Life Course Savings Scheme are not officially registered as retired when they take up funds from this program to finance retirement. We should therefore also not expect to see an effect on retirement realizations. The lack of significant effects for the financial decision making variables, however, could also suggest that, ultimately, when it comes to actual retirement, it is not participation in the Life Course Savings Scheme per

\footnotetext{
${ }^{18} \mathrm{We}$ also looked at differential effects by self-reported bad health, a depression indicator derived from the CESD-8 score, and subjective survival probabilities. Of these variables, only the latter showed significantly different treatment effects.
} 
se but also the need to have sufficient other means to cushion the impact of the reduction in pension wealth on retirement. To test for this, one needs to further stratify the groups, but we ran into power problems and therefore did not pursue this further. ${ }^{19}$ A further question that remains is why do we find significant heterogeneous treatment effects by wage, education, and health for retirement realizations and why are the same heterogeneous responses not statistically significant for retirement expectations in 2007? Note that the retirement status is observed at a point in time and thus looks at the differences between those who have retired and those who have not at a point in time, while our retirement expectations variable measures the change in expectations for all workers (some of whom may have retired by 2011 and some who have not).

To summarize the above, we find heterogeneous effects for different subgroups but primarily for retirement realizations in 2014 and participation in the Life Course Savings Scheme. The most notable differences in actual retirement behavior are found for the wage, education, and health variables and, for savings, the variables related to risk aversion and (financial) decision making in complex situations.

\section{Summary, discussion, and conclusion}

This paper looks at the response of retirement expectations, actual retirement, and savings to an unanticipated reform of the pension system that was implemented in January 2006. The reform affected workers born in 1950 (or later) and led to a substantial loss in pension wealth. Those born prior to 1950 (controls) could retire at the age of 62 with a replacement rate of $70 \%$ of the average of wages earned in the past 10 years. The affected cohort in our sample (treated) had to work 13 months longer to obtain the same replacement rate or they could retire at age 62 with a

\footnotetext{
${ }^{19}$ Note that, besides being able to save sufficient amounts of money to finance earlier retirement, they also hold more alternative sources of wealth from which they can finance earlier retirement.
} 
replacement rate of $64 \%$. At the same time, the government launched a tax-facilitated savings program, the Life Course Savings Scheme, that permitted tax-free savings up to $12 \%$ of one's annual income. This program was open to all workers (treated and controls).

We find strong behavioral responses to the reform. The expectation data show that, one year after the reform, affected workers expected, on average, to work about 10.5 months longer. The drop in pension wealth is equivalent to 13 months of earlier retirement, so our results suggest that the average treated worker makes up for the drop in their pension rights mainly at the expense of leisure in retirement and, to a lesser extent, by decreasing post-retirement consumption. The difference in retirement expectations between the treated and control groups remained stable in later years and is close to the differences in actual retirement rates observed in 2014. Observed retirement patterns by age indicate that the affected workers work an additional year, as intended by the program. It thus appears that that the reform was very effective in raising the retirement age for the larger part of the sample.

The savings rates of the treated, as measured by participation in the tax-facilitated retirement savings program, are around $16 \%$, which is more than twice the savings rate of the controls. Those in the control and treated cohorts participating in the program stated that they expected to finance about nine months and 13 months of earlier retirement, respectively. The nine months' savings of the controls can be interpreted as the response to a reduction in savings costs (due to the introduction of the Life Course Savings Scheme). For the treated, the savings effect is the sum of increased private savings induced by the drop in public pension wealth and additional savings induced by the lower cost of savings. The four months' difference between the treated and controls can therefore be interpreted as the pure savings effect implied by the drop in pension wealth, that is, the pure crowding out effect between public and private wealth. All in 
all, this means that the treated participating in the Life Course Savings Scheme are likely to fully counter the drop in public pension wealth by additional savings in the Life Course Savings Scheme.

The effectiveness of the reform for the larger part of the workers could have to do with its implementation. The reform was unexpected, implemented shortly after its announcement, and late in the game for the workers studied here. At the time of the implementation in January 2006, the affected cohort in our sample was 56 years old, leaving them with six years to save a oneyear leave if they desired retiring at age 62 rather than at age 63. It is conceivable that this was not possible for the larger part of the workers (i.e., the $84 \%$ of the treated who did not participate in the savings program) unless they were willing to sacrifice (much of their) current consumption to finance earlier retirement. These workers thus had to face the choice to work longer and/or accept a loss in post-retirement consumption. Our findings indicate that workers not participating in the savings program chose to work substantially longer. It thus appears that, for these workers, the stabilization of post-retirement income/consumption was the main motive and this was derived at no loss in current consumption. This result is consistent with the very low substitution rates between private and public wealth for older workers faced with reforms at the end of their working life.

The $16 \%$ of workers born in 1950 who participated in the Life Course Savings Scheme stuck to their previously planned retirement date. These workers were mostly high-wage workers who also held more alternative sources of wealth, allowing them to absorb the loss in pension wealth with private wealth. For these workers, private wealth fully crowded out public pension wealth. Those not participating in the Life Course Savings Scheme expected to postpone retirement with 12.5 months. These were generally lower-wage workers who, on average, were 
also in worse health. This result suggests that the zero substitution rate between private and public health is primarily due to financial constraints rather than a low disutility of work. The question is whether the stronger labor supply effects of the pension reform on particular workers in worse health are really desirable from a government perspective. A further unintended side effect of the introduction of the tax-facilitated savings plan is that, in particular, high-wage earners who participated in the savings program but who were not affected by the pension reform (the controls) decided to retire even sooner than initially planned.

Are the results generalizable to other countries, other sectors, and other workers? Obviously, our findings cannot be generalized to younger cohorts that are also affected by the reform. Cohorts born, say, in the 1960s have more time to accumulate private wealth and, therefore, the effects of the reform will likely be smaller for these cohorts and, presumably, lower-wage workers could, in the longer run, be able to compensate for the loss in public pension wealth by increased savings. Additionally, it is unclear whether the same extension of working life can be expected in other sectors of the economy. The public sector is atypical in the sense that workers are, on average, much more educated and face different working conditions than workers in other sectors of the economy. In sectors with strenuous working conditions, such as construction, workers' health can limit working life extension and, therefore, the effect of a similar reform on retirement rates could be smaller in the first instance. However, workers in these sectors are also less educated, have lower wages, and are likely to have less wealth to compensate for losses in pension wealth.

The essential lesson from this paper is that reforms announced late in the game have substantial effects on retirement patterns, but most of the effect is confined to workers who are financially constrained and who cannot counter public pension wealth losses with private wealth. 
These are generally lower-wage workers with lower education levels and in worse health. This information is relevant for workers in all countries, irrespective of the specifics of the country's pension system.

\section{Literature}

Alessie, R., Angelini, V., \& Van Santen, P. (2013). Pension wealth and household savings in Europe: Evidence from SHARELIFE. European Economic Review, 63, 308-328.

Attanasio, O \& A. Bruggiavini (2003) Social Security and Household's Saving, Quarterly Journal of Economics, vol.118, n.3

Attanasio, O. P., \& Rohwedder, S. (2003). Pension wealth and household saving: Evidence from pension reforms in the United Kingdom. The American Economic Review, 93(5), 14991521.

Banks, J., Marmot, M, Oldfield, Z and J Smit (2006). Disease and Disadvantage in the United States and in England, Journal of the American Medical Association (JAMA) 295(17):2037-2045, May 3, 2006 (with James Banks, Michael Marmot, and Zoe Oldfield)

Banks, J., Emmerson, C., \& Tetlow, G. (2007). Healthy retirement or unhealthy inactivity: How important are financial incentives in explaining retirement. Journal of Public Economics, 89, 427-440.

Banks, J., o’Dea, C., \& Oldfield, Z. (2010). Cognitive function, numeracy and retirement saving trajectories. The Economic Journal, 120(548).

Benitez-Silva, H., \& Dwyer, D. S. (2005). The rationality of retirement expectations and the role of new information. Review of Economics and Statistics, 87(3), 587-592.

Bernheim, B. D. (1989). The Timing of Retirement: A Comparison of Expectations and Realizations. In The Economics of Aging (pp. 335-358). University of Chicago Press.

Bernheim, B. D. (2002). Taxation and saving. Handbook of public economics, 3, 1173-1249.

Bernheim, B. D. (2009). 11 The Timing of Retirement: A Comparison of Expectations and Realizations. The Economics of Aging, 335.

Bloemen, H., Hochguertel, S., \& Zweerink, J. (2015). Joint Retirement of Couples: Evidence from a Natural Experiment. IZA DP No. 8861. 
Bottazzi, R., Jappelli, T., \& Padula, M. (2006). Retirement expectations, pension reforms, and their impact on private wealth accumulation. Journal of Public Economics, 90(12), 21872212.

Bovenberg, L., \& Gradus, R (2015). Reforming occupational pension schemes: the case of the Netherlands. Journal of Economic Policy Reform, 18(3), 244-257.

Chan, S., \& Stevens, A. H. (2004). Do changes in pension incentives affect retirement? A longitudinal study of subjective retirement expectations. Journal of Public Economics, 88(7), 1307-1333.

Dohmen, T., Falk, A., Huffman, D., Sunde, U., Schupp, J., \& Wagner, G. G. (2011). Individual risk attitudes: Measurement, determinants, and behavioral consequences. Journal of the European Economic Association, 9(3), 522-550.

Dwyer, D. S., \& Hu, J. (2000). Retirement expectations and realizations: The role of health shocks and economic factors. Forecasting retirement needs and retirement wealth, 274287.

Euwals, R.W., D.J. van Vuuren, and R.P. Wolthoff (2006). `Early retirement behavior in the Netherlands: Evidence from a policy reform.' Tinbergen Institute Discussion Paper 2006$021 / 3$

Feldstein, M. (1974). Social security, induced retirement, and aggregate capital accumulation. Journal of Political Economy, 82(5), 905-926.

Feldstein, M., \& Pellechio, A. (1979). Social Security and Household Accumulation: New Microeconometric Evidence. Review of Economics and Statistics, 61(3). 361-368.

Gale, W. G. (1998). The effects of pensions on household wealth: A reevaluation of theory and evidence. Journal of Political Economy, 106(4), 706-723.

Grip, A. D., Lindeboom, M., \& Montizaan, R. (2012). Shattered dreams: the effects of changing the pension system late in the game. The Economic Journal, 122(559), 1-25.

Gustman, A.L., and TL. Steinmeier. "Social security, pensions and retirement behaviour within the family." Journal of Applied Econometrics 19.6 (2004): 723-737.

Lindeboom, M., and Kerkhofs, M. (2009). Health and work of the elderly: subjective health measures, reporting errors and endogeneity in the relationship between health and work. Journal of Applied Econometrics, 24(6), 1024-1046.

Lindeboom, M. and M. Melnychuk (2015), Mental Health and Asset Choices, Annales 
d'Économie et de Statistique, 119(120), 65-94.

McFall, B. H. (2011). Crash and wait? The impact of the Great Recession on the retirement plans of older Americans. The American Economic Review, 101(3), 40-44.

Montizaan, R., Cörvers, F., \& De Grip, A. (2010). The effects of pension rights and retirement age on training participation: Evidence from a natural experiment. Labour Economics, 17(1), 240-247.

Montizaan, R., De Grip, A., Cörvers, F., \& Dohmen, T. (2015). The impact of negatively reciprocal inclinations on worker behavior: Evidence from a retrenchment of pension rights. Management Science, 62(3), 668-681.

Montizaan, R. M., \& Vendrik, M. C. (2014). Misery loves company: Exogenous shocks in retirement expectations and social comparison effects on subjective well-being. Journal of Economic Behavior \& Organization, 97, 1-26.

OECD, 2015. Pensions at a glance 2015: OECD and G20 indicators. Paris: OECD Publishing. http://dx.doi.org/10.1787/pension_glance-2015-en

Radloff, L.S. (1977). 'The CES-D scale: a self-report depression scale for research in the general population', Applied Psychological Measurement, vol. 1(3), pp. 385-401.

Rouwendal, J. (2009). Housing wealth and household portfolios in an ageing society. De Economist, 157(1), 1-48.

Statistics Netherlands (2009). 'Labour force survey.' Statline 
Table 1 Characteristics for the affected and not affected respondent (2007)

\begin{tabular}{|c|c|c|c|c|c|}
\hline & $\begin{array}{l}\text { Affected by } \\
\text { the reform }\end{array}$ & $\begin{array}{c}\text { Not affected } \\
\text { by the } \\
\text { reform }\end{array}$ & Min & Max & P-value ${ }^{1}$ \\
\hline \multicolumn{6}{|l|}{ Personal characteristics } \\
\hline Low education level & 0.132 & 0.125 & 0 & 1 & 0.835 \\
\hline High education level & 0.671 & 0.681 & 0 & 1 & 0.532 \\
\hline Married & 0.904 & 0.919 & 0 & 1 & 0.661 \\
\hline Number of sick days & 9.47 & 8.89 & 0 & 250 & 0.741 \\
\hline \multicolumn{6}{|l|}{ Job characteristics } \\
\hline \# years contributed to pension fund & 30.262 & 31.762 & 10 & 45.579 & 0.565 \\
\hline Log wage & 10.788 & 10.801 & 9.69 & 12.89 & 0.748 \\
\hline Number of contractual work hours & 0.996 & 0.996 & 0.26 & 1.25 & 0.945 \\
\hline \multicolumn{6}{|l|}{ Sectors } \\
\hline Government & 0.481 & 0.452 & 0 & 1 & 0.756 \\
\hline Education & 0.446 & 0.479 & 0 & 1 & 0.618 \\
\hline Privatized & 0.073 & 0.069 & 0 & 1 & 0.715 \\
\hline \multicolumn{6}{|l|}{ Income and savings } \\
\hline Life course savings & 0.155 & 0.064 & 0 & 1 & 0.000 \\
\hline Extra pension savings in previous year & 0.254 & 0.210 & 0 & 1 & 0.191 \\
\hline Partner with own income & 0.749 & 0.728 & 0 & 1 & 0.154 \\
\hline Partner with own pension & 0.571 & 0.572 & 0 & 1 & 0.816 \\
\hline positive net housing wealth & 0.687 & 0.684 & 0 & 1 & 0.271 \\
\hline Number of alternative wealth sources & 2.365 & 2.359 & 0 & 9 & 0.702 \\
\hline \multicolumn{6}{|l|}{ Retirement expectations } \\
\hline Expected retirement benefit & 66.725 & 72.272 & 30 & 135 & 0.000 \\
\hline Expected retirement age & 63.472 & 62.734 & 57 & 70 & 0.000 \\
\hline Expected retirement age before reform & 61.390 & 61.489 & 53 & 70 & 0.620 \\
\hline
\end{tabular}

1 The last column reports the p-values of the treatment dummy from a regression of the variable in question on treatment and age. 
Table 2 Expected age of retirement in 2007 and the difference between the expected age of retirement in 2007 and 2002: OLS results

\begin{tabular}{|c|c|c|c|c|}
\hline \multirow{2}{*}{ Dependent variable: } & (1) & (2) & (3) & (4) \\
\hline & \multicolumn{2}{|c|}{$\begin{array}{l}\text { ER(2007)-ER(2002) } \\
\text { Change in Retirement } \\
\text { expectations }\end{array}$} & \multicolumn{2}{|c|}{$\begin{array}{c}\text { ER(2007) } \\
\text { Expected Retirement Age } 2007\end{array}$} \\
\hline Treatment dummy & $\begin{array}{c}0.845^{* * *} \\
(0.102)\end{array}$ & $\begin{array}{l}0.879^{* * * *} \\
(0.102)\end{array}$ & $\begin{array}{c}0.814^{* * *} \\
(0.081)\end{array}$ & $\begin{array}{l}0.814^{* * *} \\
(0.081)\end{array}$ \\
\hline Birth date / 1000 & $\begin{array}{l}-0.042 \\
(0.240)\end{array}$ & $\begin{array}{l}-0.047 \\
(0.239)\end{array}$ & $\begin{array}{l}-0.208 \\
(0.194)\end{array}$ & $\begin{array}{l}-0.274 \\
(0.192)\end{array}$ \\
\hline Birthdate squared & $\begin{array}{l}-1.463^{* *} \\
(0.626)\end{array}$ & $\begin{array}{l}-1.426^{* *} \\
(0.627)\end{array}$ & $\begin{array}{l}-0.144 \\
(0.511)\end{array}$ & $\begin{array}{l}-0.242 \\
(0.505)\end{array}$ \\
\hline Married & & $\begin{array}{l}0.264^{* * *} \\
(0.097)\end{array}$ & & $\begin{array}{c}0.057 \\
(0.079)\end{array}$ \\
\hline Low educated & & $\begin{array}{l}-0.015 \\
(0.102)\end{array}$ & & $\begin{array}{c}-0.229^{* * * *} \\
(0.077)\end{array}$ \\
\hline High educated & & $\begin{array}{l}-0.205^{* *} \\
(0.086)\end{array}$ & & $\begin{array}{c}0.063 \\
(0.068)\end{array}$ \\
\hline Wage (ln) & & $\begin{array}{c}-0.385^{* * *} \\
(0.124)\end{array}$ & & $\begin{array}{c}0.124 \\
(0.103)\end{array}$ \\
\hline $\begin{array}{l}\text { Number of contribution years to } \\
\text { the pension fund }\end{array}$ & & $\begin{array}{l}0.028^{* * * *} \\
(0.005)\end{array}$ & & $\begin{array}{c}-0.052^{* * *} \\
(0.004)\end{array}$ \\
\hline Constant & $\begin{array}{l}1.313^{* * *} \\
(0.065)\end{array}$ & $\begin{array}{l}4.624^{* * * *} \\
(1.322)\end{array}$ & $\begin{array}{c}62.701^{* * * *} \\
(0.050)\end{array}$ & $\begin{array}{l}62.993^{* * *} \\
(1.099)\end{array}$ \\
\hline $\begin{array}{l}\text { Observations } \\
\text { Adjusted } R^{2}\end{array}$ & $\begin{array}{l}6605 \\
0.041\end{array}$ & $\begin{array}{r}6476 \\
0.062\end{array}$ & $\begin{array}{c}6702 \\
0.046\end{array}$ & $\begin{array}{r}6569 \\
0.093\end{array}$ \\
\hline
\end{tabular}

Standard errors in parentheses. Other control variables included in Columns 2 and 4: sector dummies.

$* \mathrm{p}<0.10, * * \mathrm{p}<0.05, * * * \mathrm{p}<0.01$ 
Table 3 Savings in 2007: results from a linear probability model

\begin{tabular}{|c|c|c|c|c|}
\hline & $(1)$ & $(2)$ & (3) & $(4)$ \\
\hline Dependent variable: & \multicolumn{2}{|c|}{ Life course savings } & \multicolumn{2}{|c|}{$\begin{array}{l}\text { Extra pension savings } \\
\text { in previous year }\end{array}$} \\
\hline Treatment dummy & $\begin{array}{l}0.082^{* * * *} \\
(0.017)\end{array}$ & $\begin{array}{c}0.083^{* * *} \\
(0.017)\end{array}$ & $\begin{array}{c}0.027 \\
(0.021)\end{array}$ & $\begin{array}{c}0.028 \\
(0.021)\end{array}$ \\
\hline Birth date / 1000 & $\begin{array}{c}0.026 \\
(0.041)\end{array}$ & $\begin{array}{c}0.020 \\
(0.040)\end{array}$ & $\begin{array}{c}0.047 \\
(0.050)\end{array}$ & $\begin{array}{c}0.026 \\
(0.049)\end{array}$ \\
\hline Birth date squared & $\begin{array}{c}0.042 \\
(0.108)\end{array}$ & $\begin{array}{c}0.030 \\
(0.107)\end{array}$ & $\begin{array}{l}-0.013 \\
(0.131)\end{array}$ & $\begin{array}{l}-0.022 \\
(0.129)\end{array}$ \\
\hline Married & & $\begin{array}{c}0.016 \\
(0.014)\end{array}$ & & $\begin{array}{c}0.022 \\
(0.018)\end{array}$ \\
\hline Low educated & & $\begin{array}{l}-0.004 \\
(0.013)\end{array}$ & & $\begin{array}{l}-0.061^{* * * *} \\
(0.017)\end{array}$ \\
\hline High educated & & $\begin{array}{c}0.018 \\
(0.014)\end{array}$ & & $\begin{array}{c}0.019 \\
(0.017)\end{array}$ \\
\hline Wage (ln) & & $\begin{array}{c}0.090^{* * *} \\
(0.022)\end{array}$ & & $\begin{array}{c}0.010 \\
(0.026)\end{array}$ \\
\hline $\begin{array}{l}\text { Number of contribution years to } \\
\text { the pension fund }\end{array}$ & & $\begin{array}{c}-0.003^{* * *} \\
(0.001)\end{array}$ & & $\begin{array}{c}-0.010^{* * * *} \\
(0.001)\end{array}$ \\
\hline Constant & $\begin{array}{l}0.067^{* * *} \\
(0.009)\end{array}$ & $\begin{array}{c}-0.843^{* * *} \\
(0.229)\end{array}$ & $\begin{array}{l}0.219^{* * *} \\
(0.013)\end{array}$ & $\begin{array}{c}0.393 \\
(0.271)\end{array}$ \\
\hline $\begin{array}{l}\text { Observations } \\
\text { Adjusted } R^{2}\end{array}$ & $\begin{array}{l}5245 \\
0.020\end{array}$ & $\begin{array}{l}5244 \\
0.039\end{array}$ & $\begin{array}{c}6645 \\
0.002\end{array}$ & $\begin{array}{c}6633 \\
0.026\end{array}$ \\
\hline
\end{tabular}

Standard errors in parentheses. Other control variables included in Columns 2 and 4: sector dummies.

$* \mathrm{p}<0.10, * * \mathrm{p}<0.05, * * * \mathrm{p}<0.01$ 
Table 4 Months early retirement financed from the life course savings program in 2009: OLS results

\begin{tabular}{|c|c|c|}
\hline \multirow{3}{*}{ Dependent variable: } & \multirow{2}{*}{\multicolumn{2}{|c|}{$\begin{array}{l}(1) \\
\text { Months early retirement financed from the } \\
\text { life course savings program }\end{array}$}} \\
\hline & & \\
\hline & Column 1 & Column 2 \\
\hline Treatment dummy & $\begin{array}{l}4.241^{* *} \\
(1.748)\end{array}$ & $\begin{array}{l}4.323^{* *} \\
(1.830)\end{array}$ \\
\hline Birth date / 1000 & $\begin{array}{c}0.476 \\
(4.168)\end{array}$ & $\begin{array}{l}-0.196 \\
(4.287)\end{array}$ \\
\hline Birth date squared & $\begin{array}{c}3.596 \\
(10.846)\end{array}$ & $\begin{array}{c}0.728 \\
(11.180)\end{array}$ \\
\hline Married & & $\begin{array}{c}0.781 \\
(1.595)\end{array}$ \\
\hline Low educated & & $\begin{array}{l}-1.111 \\
(1.722)\end{array}$ \\
\hline High educated & & $\begin{array}{c}1.979 \\
(1.204)\end{array}$ \\
\hline Wage (ln) & & $\begin{array}{l}-1.393 \\
(1.530)\end{array}$ \\
\hline \multirow[t]{2}{*}{$\begin{array}{l}\text { Number of contribution } \\
\text { years to the pension } \\
\text { fund }\end{array}$} & & -0.092 \\
\hline & & $(0.081)$ \\
\hline Constant & $\begin{array}{l}8.972^{* * * *} \\
(1.336)\end{array}$ & $\begin{array}{c}25.255 \\
(17.126)\end{array}$ \\
\hline Observations & 601 & 589 \\
\hline Adjusted $R^{2}$ & 0.030 & 0.046 \\
\hline
\end{tabular}

Standard errors in parentheses. Other control variables included in Column 2: sector dummies. $* \mathrm{p}<0.10$, ** $\mathrm{p}<$ $0.05,{ }^{* * *} \mathrm{p}<0.01$. The number of observations is lower as we focus in this table only on workers who participate in the life course savings program. 
Table 5 Longer run effects in retirement expectations

\begin{tabular}{|c|c|c|c|c|c|}
\hline & $(1)$ & $(2)$ & (3) & (4) & $(5)$ \\
\hline $\operatorname{ER}(t)-E R(2002)$ & 2007 & 2008 & 2009 & 2010 & 2011 \\
\hline \multirow{2}{*}{$\begin{array}{l}\text { Treatment } \\
\text { dummy }\end{array}$} & $0.879^{* * * * * 1}$ & $0.803^{* * * * * 4}$ & $0.603^{* * * *}$ & $0.655^{* * *}$ & $0.753^{* * * *}$ \\
\hline & $(0.102)$ & $(0.139)$ & $(0.146)$ & $(0.158)$ & $(0.177)$ \\
\hline \multirow[t]{2}{*}{ Birth date / 1000} & -0.047 & -0.201 & 0.183 & 0.487 & 0.410 \\
\hline & $(0.239)$ & $(0.327)$ & $(0.348)$ & $(0.373)$ & $(0.428)$ \\
\hline \multirow[t]{2}{*}{ Birthdate squared } & $-1.426^{* *}$ & -0.806 & -0.741 & -1.498 & -0.487 \\
\hline & $(0.627)$ & $(0.856)$ & $(0.908)$ & $(0.991)$ & $(1.142)$ \\
\hline \multirow[t]{2}{*}{ Married } & $0.264^{* * * *}$ & $0.443^{\text {*** }}$ & $0.355^{* *}$ & $0.525^{* * *}$ & $0.489^{* * * *}$ \\
\hline & $(0.097)$ & $(0.142)$ & $(0.147)$ & $(0.169)$ & $(0.183)$ \\
\hline \multirow[t]{2}{*}{ Low educated } & -0.015 & 0.123 & 0.007 & 0.136 & 0.078 \\
\hline & $(0.102)$ & $(0.140)$ & $(0.157)$ & $(0.176)$ & $(0.245)$ \\
\hline \multirow[t]{2}{*}{ High educated } & $-0.205^{* *}$ & $-0.299^{* * *}$ & $-0.324^{* *}$ & $-0.363^{* * *}$ & -0.204 \\
\hline & $(0.086)$ & $(0.114)$ & $(0.132)$ & $(0.139)$ & $(0.155)$ \\
\hline \multirow[t]{2}{*}{ Wage (ln) } & $-0.385^{* * *}$ & -0.243 & -0.224 & -0.166 & $-0.385^{*}$ \\
\hline & $(0.124)$ & $(0.168)$ & $(0.186)$ & $(0.195)$ & $(0.224)$ \\
\hline \multirow{2}{*}{$\begin{array}{l}\text { Number of } \\
\text { contribution } \\
\text { years to the } \\
\text { pension fund }\end{array}$} & $0.028^{* * * *}$ & $0.026^{* * * *}$ & $0.032^{* * * *}$ & $0.023^{* *}$ & 0.011 \\
\hline & $(0.005)$ & $(0.007)$ & $(0.008)$ & $(0.009)$ & $(0.010)$ \\
\hline \multirow[t]{2}{*}{ Constant } & $4.624^{* * * *}$ & $3.004^{*}$ & 2.958 & 2.663 & $5.643^{* *}$ \\
\hline & $(1.322)$ & $(1.800)$ & (1.986) & $(2.092)$ & $(2.446)$ \\
\hline Observations & 6476 & 3393 & 3183 & 2615 & 2101 \\
\hline Adjusted $R^{2}$ & 0.062 & 0.058 & 0.051 & 0.074 & 0.072 \\
\hline
\end{tabular}


Table 6 Retired in 2014: results from a linear probability model

Dependent variable:

(1)

(2)

Retired in 2014

Treatment dummy

$-0.245^{* * *}$

(0.029)

$-0.553^{* * *}$

$-0.224^{* * * *}$

Birth date / 1000

$(0.062)$

(0.029)

$-0.592^{*}$

Birthdate squared

(0.062)

$0.928^{* * *}$

(0.160)

Constant

$0.623^{* * *}$

$0.569^{* * *}$

Observations

$(0.017)$

(0.020)

4419

4419

Adjusted $R^{2}$

0.214

0.219

Standard errors in parentheses. ${ }^{*} p<0.10,{ }^{* * *} p<0.05,{ }^{* * * *} p<0.01$

Table 7 Percentage of people retired by age

\begin{tabular}{lccc}
\hline Percentage of people retired at age & & Treated & Control \\
\hline 60 & 2.59 & 7.24 \\
& 61 & 6.05 & 12.84 \\
62 & 13.84 & 27.21 \\
& 63 & 26.19 & 57.30 \\
64 & 29.48 & 69.08 \\
\hline
\end{tabular}


Table 8 Heterogeneous effects on the expected retirement age and life course savings in 2007 and actual retirement in 2014

\begin{tabular}{|c|c|c|c|c|c|c|c|c|c|c|c|c|c|c|}
\hline \multirow{3}{*}{$\begin{array}{l}\text { ER(2007)- } \\
\text { ER(2002) } \\
\text { Dependent } \\
\text { variable: Expected } \\
\text { retirement age in } \\
2007\end{array}$} & (1) & (2) & (3) & (4) & (5) & (6) & (7) & (8) & (9) & (10) & (11) & (12) & (13) & (14) \\
\hline & \multicolumn{8}{|c|}{ Income, education, partner has pension and health } & \multicolumn{6}{|c|}{ Financial decision making } \\
\hline & $\begin{array}{c}\text { Wage top } \\
25 \%\end{array}$ & $\begin{array}{l}\text { Wage } \\
\text { other }\end{array}$ & $\begin{array}{c}\text { High } \\
\text { education } \\
\text { level }\end{array}$ & $\begin{array}{c}\text { Other } \\
\text { education } \\
\text { (low and } \\
\text { intermediate) } \\
\text { levels } \\
\end{array}$ & $\begin{array}{c}\text { Partner has } \\
\text { own pension } \\
\end{array}$ & $\begin{array}{c}\text { Partner has } \\
\text { no own } \\
\text { pension }\end{array}$ & $\begin{array}{c}\text { Number of } \\
\text { sick days top } \\
25 \%\end{array}$ & $\begin{array}{c}\text { Number of } \\
\text { sick days } \\
\text { other }\end{array}$ & $\begin{array}{c}\text { Risk } \\
\text { aversion top } \\
25 \%\end{array}$ & $\begin{array}{c}\text { Risk } \\
\text { aversion } \\
\text { other }\end{array}$ & $\begin{array}{c}\text { Financial } \\
\text { Risk } \\
\text { aversion top } \\
25 \%\end{array}$ & $\begin{array}{c}\text { Financial } \\
\text { Risk } \\
\text { aversion } \\
\text { other }\end{array}$ & $\begin{array}{l}\text { Capability to } \\
\text { take difficult t } \\
\text { decisions } \\
\text { bottom } 25 \%\end{array}$ & $\begin{array}{l}\text { Capability to } \\
\text { ake difficult } \\
\text { decisions } \\
\text { other }\end{array}$ \\
\hline Treatment dummy & $\begin{array}{c}0.957^{* * * *} \\
(0.183)\end{array}$ & $\begin{array}{c}0.827 * * * \\
(0.121)\end{array}$ & $\begin{array}{c}0.936 * * * \\
(0.116)\end{array}$ & $\begin{array}{c}0.715^{* * *} \\
(0.198)\end{array}$ & $\begin{array}{c}0.872 * * * \\
(0.140)\end{array}$ & $\begin{array}{c}0.954 * * * \\
(0.180)\end{array}$ & $\begin{array}{c}1.041 * * * \\
(0.239)\end{array}$ & $\begin{array}{c}0.746^{* * *} \\
(0.138)\end{array}$ & $\begin{array}{c}1.149^{* * * *} \\
(0.223)\end{array}$ & $\begin{array}{c}0.828 * * * \\
(0.131)\end{array}$ & $\begin{array}{c}1.258^{* * * *} \\
(0.215)\end{array}$ & $\begin{array}{c}0.716 * * * \\
(0.170)\end{array}$ & $\begin{array}{c}0.509 \\
(0.316)\end{array}$ & $\begin{array}{c}0.848^{* * * *} \\
(0.285)\end{array}$ \\
\hline Birth date / 1000 & $\begin{array}{l}-0.006 \\
(0.435)\end{array}$ & $\begin{array}{l}-0.101 \\
(0.285)\end{array}$ & $\begin{array}{l}-0.137 \\
(0.275)\end{array}$ & $\begin{array}{c}0.081 \\
(0.464)\end{array}$ & $\begin{array}{c}0.100 \\
(0.324)\end{array}$ & $\begin{array}{l}-0.188 \\
(0.430)\end{array}$ & $\begin{array}{l}-0.528 \\
(0.592)\end{array}$ & $\begin{array}{c}0.209 \\
(0.329)\end{array}$ & $\begin{array}{l}-0.792 \\
(0.530)\end{array}$ & $\begin{array}{l}-0.069 \\
(0.315)\end{array}$ & $\begin{array}{c}-0.955^{*} \\
(0.494)\end{array}$ & $\begin{array}{c}0.143 \\
(0.403)\end{array}$ & $\begin{array}{l}1.271^{*} \\
(0.743)\end{array}$ & $\begin{array}{l}-0.344 \\
(0.685)\end{array}$ \\
\hline Birthdate squared & $\begin{array}{c}0.127 \\
(1.148)\end{array}$ & $\begin{array}{c}-1.953 * * * \\
(0.741)\end{array}$ & $\begin{array}{l}-0.380 \\
(0.720)\end{array}$ & $\begin{array}{c}-3.296^{* * *} \\
(1.211)\end{array}$ & $\begin{array}{c}-1.642^{*} \\
(0.838)\end{array}$ & $\begin{array}{l}-0.694 \\
(1.145)\end{array}$ & $\begin{array}{l}-0.535 \\
(1.603)\end{array}$ & $\begin{array}{c}-1.660^{*} \\
(0.865)\end{array}$ & $\begin{array}{l}-0.138 \\
(1.423)\end{array}$ & $\begin{array}{c}-1.526^{*} \\
(0.823)\end{array}$ & $\begin{array}{l}-0.999 \\
(1.271)\end{array}$ & $\begin{array}{l}-0.981 \\
(1.053)\end{array}$ & $\begin{array}{c}-4.056 * * \\
(1.963)\end{array}$ & $\begin{array}{l}-0.696 \\
(1.814)\end{array}$ \\
\hline Constant & $\begin{array}{c}0.954 * * * \\
(0.119)\end{array}$ & $\begin{array}{c}1.420 * * * \\
(0.076)\end{array}$ & $\begin{array}{c}1.081 * * * \\
(0.074)\end{array}$ & $\begin{array}{c}1.739 * * * \\
(0.123)\end{array}$ & $\begin{array}{c}1.263^{* * * *} \\
(0.089)\end{array}$ & $\begin{array}{c}1.420 * * * \\
(0.115)\end{array}$ & $\begin{array}{c}1.375^{* * * *} \\
(0.154)\end{array}$ & $\begin{array}{c}1.381 * * * \\
(0.090)\end{array}$ & $\begin{array}{c}1.181 * * * \\
(0.149)\end{array}$ & $\begin{array}{c}1.349 * * * \\
(0.082)\end{array}$ & $\begin{array}{c}1.133 * * * \\
(0.135)\end{array}$ & $\begin{array}{c}1.379^{* * * *} \\
(0.105)\end{array}$ & $\begin{array}{c}1.822 * * * \\
(0.236)\end{array}$ & $\begin{array}{c}1.304 * * * \\
(0.201)\end{array}$ \\
\hline $\begin{array}{l}\text { Observations } \\
\text { P-value test } \\
\text { whether the } \\
\text { difference in the } \\
\text { treatment dummy is } \\
\text { significant }\end{array}$ & $\begin{array}{l}1,647 \\
\mathbf{0 . 5 5 4}\end{array}$ & 4,958 & $\begin{array}{l}4,438 \\
\mathbf{0 . 3 3 6}\end{array}$ & 2,139 & $\begin{array}{l}3,279 \\
\mathbf{0 . 6 6 5}\end{array}$ & 2,092 & $\begin{array}{l}1,122 \\
\mathbf{0 . 2 8 6}\end{array}$ & 3,148 & $\begin{array}{l}1,191 \\
\mathbf{0 . 2 1 4}\end{array}$ & 3,801 & $\begin{array}{l}1,418 \\
\mathbf{0 . 0 4 8}\end{array}$ & 2,204 & $\begin{array}{c}669 \\
\mathbf{0 . 4 2 6}\end{array}$ & 817 \\
\hline R-squared & 0.061 & 0.037 & 0.052 & 0.031 & 0.053 & 0.047 & 0.042 & 0.046 & 0.051 & 0.040 & 0.054 & 0.038 & 0.061 & 0.030 \\
\hline \multicolumn{15}{|l|}{$\begin{array}{l}\text { Life course } \\
\text { savings in } 2007 \\
\end{array}$} \\
\hline Treatment dummy & $\begin{array}{c}0.088^{* *} \\
(0.038)\end{array}$ & $\begin{array}{c}0.079^{* * *} \\
(0.019)\end{array}$ & $\begin{array}{c}0.087 * * * \\
(0.022)\end{array}$ & $\begin{array}{c}0.069^{* * *} * \\
(0.026)\end{array}$ & $\begin{array}{c}0.056^{* * *} \\
(0.025)\end{array}$ & $\begin{array}{c}0.080^{* * * *} \\
(0.024)\end{array}$ & $\begin{array}{c}0.057 \\
(0.036)\end{array}$ & $\begin{array}{c}0.086^{* * * *} \\
(0.025)\end{array}$ & $\begin{array}{c}0.018 \\
(0.038)\end{array}$ & $\begin{array}{c}0.105^{* * * *} \\
(0.022)\end{array}$ & $\begin{array}{c}0.032 \\
(0.035)\end{array}$ & $\begin{array}{c}0.125^{* * * *} \\
(0.029)\end{array}$ & $\begin{array}{c}0.000 \\
(0.055)\end{array}$ & $\begin{array}{c}0.143 * * * \\
(0.044)\end{array}$ \\
\hline Birth date / 1000 & $\begin{array}{c}0.140 \\
(0.093)\end{array}$ & $\begin{array}{l}-0.011 \\
(0.043)\end{array}$ & $\begin{array}{c}0.048 \\
(0.052)\end{array}$ & $\begin{array}{l}-0.019 \\
(0.062)\end{array}$ & $\begin{array}{c}0.117 * * \\
(0.060)\end{array}$ & $\begin{array}{l}-0.035 \\
(0.057)\end{array}$ & $\begin{array}{c}0.027 \\
(0.088)\end{array}$ & $\begin{array}{c}0.022 \\
(0.060)\end{array}$ & $\begin{array}{l}0.202^{* *} \\
(0.094)\end{array}$ & $\begin{array}{l}-0.025 \\
(0.054)\end{array}$ & $\begin{array}{l}0.129 \\
(0.087)\end{array}$ & $\begin{array}{l}-0.038 \\
(0.071)\end{array}$ & $\begin{array}{c}0.171 \\
(0.131)\end{array}$ & $\begin{array}{l}-0.096 \\
(0.116)\end{array}$ \\
\hline Birthdate squared & $\begin{array}{c}0.394 \\
(0.252)\end{array}$ & $\begin{array}{l}-0.079 \\
(0.114)\end{array}$ & $\begin{array}{c}0.106 \\
(0.139)\end{array}$ & $\begin{array}{l}-0.098 \\
(0.160)\end{array}$ & $\begin{array}{c}0.100 \\
(0.160)\end{array}$ & $\begin{array}{c}0.004 \\
(0.151)\end{array}$ & $\begin{array}{c}0.078 \\
(0.244)\end{array}$ & $\begin{array}{l}-0.059 \\
(0.161)\end{array}$ & $\begin{array}{c}0.260 \\
(0.252)\end{array}$ & $\begin{array}{c}0.014 \\
(0.146)\end{array}$ & $\begin{array}{c}0.225 \\
(0.228)\end{array}$ & $\begin{array}{c}0.158 \\
(0.192)\end{array}$ & $\begin{array}{l}-0.037 \\
(0.341)\end{array}$ & $\begin{array}{l}0.414 \\
(0.323)\end{array}$ \\
\hline Constant & $\begin{array}{c}0.090 * * * \\
(0.022)\end{array}$ & $\begin{array}{c}0.059 * * * \\
(0.010)\end{array}$ & $\begin{array}{c}0.077 * * * \\
(0.012)\end{array}$ & $\begin{array}{c}0.045^{* * * *} \\
(0.014)\end{array}$ & $\begin{array}{c}0.088^{* * * *} \\
(0.014)\end{array}$ & $\begin{array}{c}0.042 * * * \\
(0.012)\end{array}$ & $\begin{array}{c}0.060 * * * \\
(0.022)\end{array}$ & $\begin{array}{c}0.080 * * * \\
(0.014)\end{array}$ & $\begin{array}{c}0.086 * * * \\
(0.023)\end{array}$ & $\begin{array}{c}0.063 * * * \\
(0.012)\end{array}$ & $\begin{array}{c}0.076^{* * * *} \\
(0.020)\end{array}$ & $\begin{array}{c}0.045^{* * * *} \\
(0.015)\end{array}$ & $\begin{array}{c}0.097 * * \\
(0.040)\end{array}$ & $\begin{array}{c}0.026 \\
(0.025)\end{array}$ \\
\hline $\begin{array}{l}\text { Observations } \\
\text { P-value test } \\
\text { whether the } \\
\text { difference in the } \\
\text { treatment dummy is } \\
\text { significant }\end{array}$ & $\begin{array}{l}1,388 \\
\mathbf{0 . 8 2 1}\end{array}$ & 3,857 & $\begin{array}{l}3,615 \\
\mathbf{0 . 6 0 6}\end{array}$ & 1,629 & $\begin{array}{l}2,656 \\
\mathbf{0 . 4 8 1}\end{array}$ & 2,055 & $\begin{array}{c}893 \\
\mathbf{0 . 5 1 5}\end{array}$ & 2,575 & $\begin{array}{c}975 \\
\mathbf{0 . 0 4 7}\end{array}$ & 3,084 & $\begin{array}{l}1,151 \\
\mathbf{0 . 0 4 3}\end{array}$ & 1,806 & $\begin{array}{c}546 \\
\mathbf{0 . 0 4 3}\end{array}$ & 681 \\
\hline R-squared & 0.040 & 0.016 & 0.025 & 0.014 & 0.024 & 0.015 & 0.013 & 0.020 & 0.026 & 0.022 & 0.020 & 0.030 & 0.012 & 0.023 \\
\hline
\end{tabular}


Table 8 continued

\begin{tabular}{|c|c|c|c|c|c|c|c|c|c|c|c|c|c|c|}
\hline \multirow{3}{*}{$\begin{array}{l}\text { Retired in } \mathbf{2 0 1 4} \\
\text { Dependent } \\
\text { variable: Retired in } \\
2014\end{array}$} & (1) & (2) & (3) & (4) & (5) & (6) & (7) & (8) & (9) & (10) & (11) & (12) & (13) & (14) \\
\hline & \multicolumn{8}{|c|}{ Income, education, partner has pension and health } & \multicolumn{6}{|c|}{ Financial decision making } \\
\hline & $\begin{array}{c}\text { Wage top } \\
25 \%\end{array}$ & $\begin{array}{l}\text { Wage } \\
\text { other }\end{array}$ & $\begin{array}{c}\text { High } \\
\text { education } \\
\text { level }\end{array}$ & $\begin{array}{c}\text { Other } \\
\text { education } \\
\text { (low and } \\
\text { intermediate) } \\
\text { levels }\end{array}$ & $\begin{array}{l}\text { Partner has } \\
\text { own pension }\end{array}$ & $\begin{array}{c}\text { Partner has } \\
\text { no own } \\
\text { pension }\end{array}$ & $\begin{array}{c}\text { Number of } \\
\text { sick days top } \\
25 \%\end{array}$ & $\begin{array}{c}\text { Number of } \\
\text { sick days } \\
\text { other }\end{array}$ & $\begin{array}{c}\text { Risk } \\
\text { aversion top } \\
25 \%\end{array}$ & $\begin{array}{c}\text { Risk } \\
\text { aversion } \\
\text { other }\end{array}$ & $\begin{array}{c}\text { Financial } \\
\text { Risk } \\
\text { aversion top } \\
25 \%\end{array}$ & $\begin{array}{l}\text { Financial } \\
\text { Risk } \\
\text { aversion } \\
\text { other }\end{array}$ & $\begin{array}{c}\text { Capability to } \\
\text { take difficult } \\
\text { decisions } \\
\text { bottom } 25 \%\end{array}$ & $\begin{array}{l}\text { Capability to } \\
\text { take difficult } \\
\text { decisions } \\
\text { other }\end{array}$ \\
\hline Treatment dummy & $\begin{array}{c}-0.180 * * * \\
(0.046)\end{array}$ & $\begin{array}{c}-0.298 * * * \\
(0.025)\end{array}$ & $\begin{array}{c}-0.222 * * * \\
(0.028)\end{array}$ & $\begin{array}{c}-0.365^{* * *} \\
(0.038)\end{array}$ & $\begin{array}{c}-0.252 * * * \\
(0.032)\end{array}$ & $\begin{array}{c}-0.320 * * * \\
(0.039)\end{array}$ & $\begin{array}{c}-0.345^{* * * *} \\
(0.052)\end{array}$ & $\begin{array}{c}-0.223 * * * * \\
(0.032)\end{array}$ & $\begin{array}{c}-0.275^{* * *} * \\
(0.050)\end{array}$ & $\begin{array}{c}-0.246 * * * \\
(0.030)\end{array}$ & $\begin{array}{c}-0.284 * * * \\
(0.048)\end{array}$ & $\begin{array}{c}-0.269 * * * \\
(0.039)\end{array}$ & $\begin{array}{c}0.015 \\
(0.078)\end{array}$ & $\begin{array}{c}0.077 \\
(0.062)\end{array}$ \\
\hline Birth date / 1000 & $\begin{array}{c}-0.709 * * * * \\
(0.101)\end{array}$ & $\begin{array}{c}-0.513 * * * \\
(0.056)\end{array}$ & $\begin{array}{c}-0.620 * * * \\
(0.061)\end{array}$ & $\begin{array}{c}-0.434 * * * \\
(0.084)\end{array}$ & $\begin{array}{c}-0.603 * * * \\
(0.069)\end{array}$ & $\begin{array}{c}-0.468 * * * \\
(0.088)\end{array}$ & $\begin{array}{c}-0.393 * * * \\
(0.118)\end{array}$ & $\begin{array}{c}-0.685^{* * *} * \\
(0.070)\end{array}$ & $\begin{array}{c}-0.602 * * * \\
(0.110)\end{array}$ & $\begin{array}{c}-0.606^{* * * *} \\
(0.066)\end{array}$ & $\begin{array}{c}-0.499 * * * \\
(0.106)\end{array}$ & $\begin{array}{c}-0.573 * * * \\
(0.084)\end{array}$ & $\begin{array}{c}-0.805^{* * * *} \\
(0.182)\end{array}$ & $\begin{array}{c}-0.940 * * * \\
(0.151)\end{array}$ \\
\hline Birthdate squared & $\begin{array}{c}0.616^{* *} \\
(0.260)\end{array}$ & $\begin{array}{c}0.509 * * * \\
(0.143)\end{array}$ & $\begin{array}{c}0.441^{* * * *} \\
(0.156)\end{array}$ & $\begin{array}{c}0.719 * * * \\
(0.216)\end{array}$ & $\begin{array}{c}0.747 * * * \\
(0.176)\end{array}$ & $\begin{array}{c}0.290 \\
(0.231)\end{array}$ & $\begin{array}{c}0.503 \\
(0.308)\end{array}$ & $\begin{array}{c}0.569 * * * \\
(0.180)\end{array}$ & $\begin{array}{c}0.794 * * * \\
(0.276)\end{array}$ & $\begin{array}{c}0.438 * * * \\
(0.168)\end{array}$ & $\begin{array}{c}0.961 * * * \\
(0.271)\end{array}$ & $\begin{array}{c}0.210 \\
(0.215)\end{array}$ & $\begin{array}{c}1.759 * * * \\
(0.468)\end{array}$ & $\begin{array}{c}2.168 * * * \\
(0.408)\end{array}$ \\
\hline Constant & $\begin{array}{c}0.568 * * * \\
(0.031)\end{array}$ & $\begin{array}{c}0.665^{* * * *} \\
(0.016)\end{array}$ & $\begin{array}{c}0.634 * * * \\
(0.018)\end{array}$ & $\begin{array}{c}0.654 * * * \\
(0.025)\end{array}$ & $\begin{array}{c}0.634 * * * \\
(0.020)\end{array}$ & $\begin{array}{c}0.667 * * * \\
(0.026)\end{array}$ & $\begin{array}{c}0.721 * * * \\
(0.034)\end{array}$ & $\begin{array}{c}0.601 * * * \\
(0.021)\end{array}$ & $\begin{array}{c}0.659 * * * \\
(0.032)\end{array}$ & $\begin{array}{c}0.633 * * * \\
(0.019)\end{array}$ & $\begin{array}{c}0.652 * * * \\
(0.030)\end{array}$ & $\begin{array}{c}0.662 * * * \\
(0.025)\end{array}$ & $\begin{array}{c}0.228 * * * \\
(0.060)\end{array}$ & $\begin{array}{c}0.188^{* * * *} \\
(0.047)\end{array}$ \\
\hline $\begin{array}{l}\text { Observations } \\
\text { P-value test } \\
\text { whether the } \\
\text { difference in the } \\
\text { treatment dummy is } \\
\text { significant }\end{array}$ & $\begin{array}{l}1,713 \\
\mathbf{0 . 0 2 4}\end{array}$ & 5,136 & $\begin{array}{l}4,589 \\
\mathbf{0 . 0 0 2}\end{array}$ & 2,204 & $\begin{array}{l}3,377 \\
\mathbf{0 . 1 8 0}\end{array}$ & 2,158 & $\begin{array}{l}1,147 \\
\mathbf{0 . 0 4 6}\end{array}$ & 3,269 & $\begin{array}{l}1,241 \\
\mathbf{0 . 5 8 2}\end{array}$ & 3,914 & $\begin{array}{l}1,465 \\
\mathbf{0 . 8 0 8}\end{array}$ & 2,268 & $\begin{array}{c}694 \\
\mathbf{0 . 3 6 4}\end{array}$ & 842 \\
\hline R-squared & 0.221 & 0.252 & 0.225 & 0.285 & 0.247 & 0.253 & 0.247 & 0.245 & 0.265 & 0.238 & 0.248 & 0.252 & 0.118 & 0.134 \\
\hline
\end{tabular}

Standard errors in parentheses. ${ }^{*} p<0.10,{ }^{* *} p<0.05,{ }^{* * *} p<0.01$ 
Figure 1 Expected retirement benefit in 2007

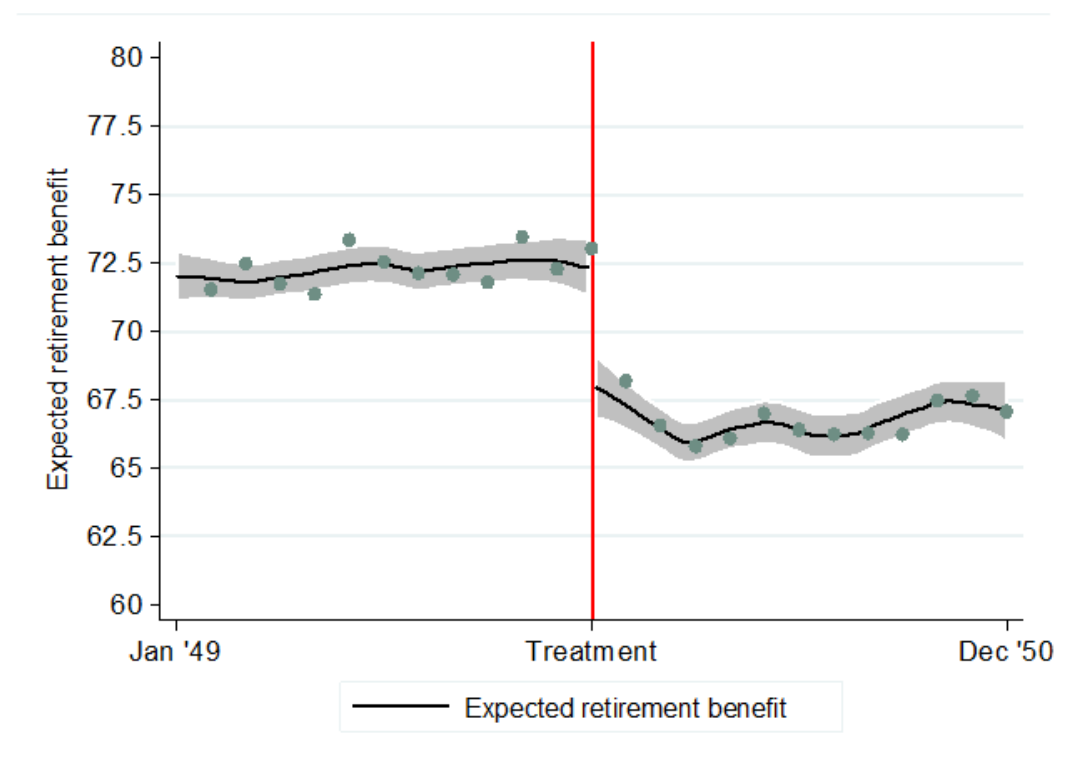

The figure presents the expected retirement benefit (for two successive birth months). The vertical line marks the threshold dividing the control and treatment groups.

\section{Figure 2 Expected retirement age before the reform}

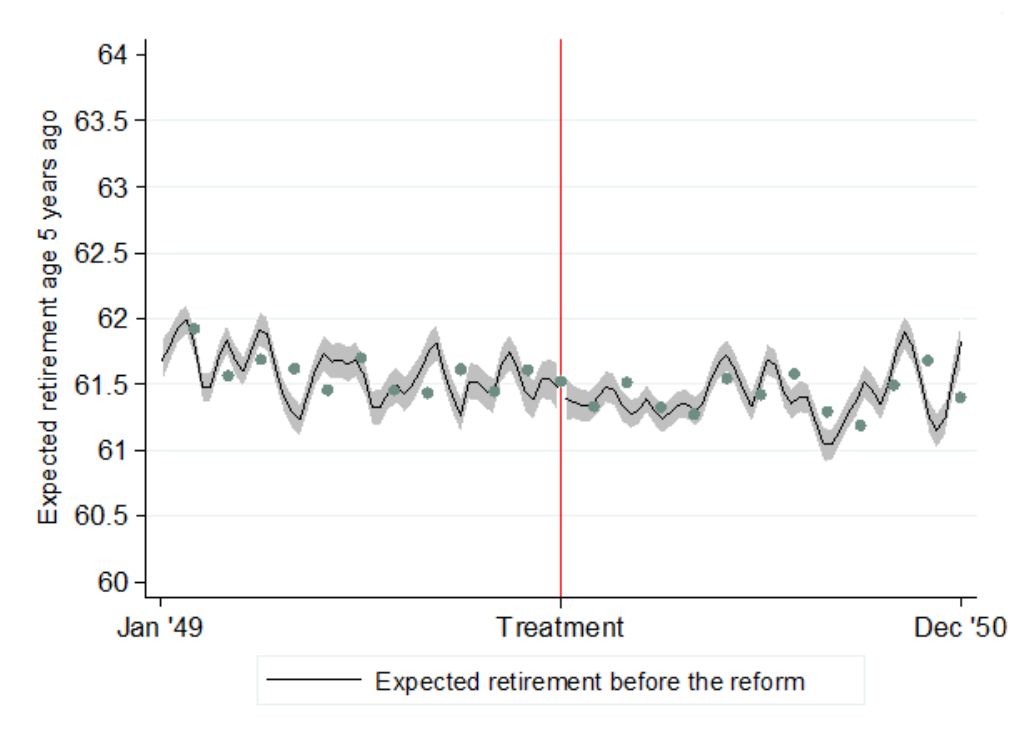

The figure presents the expected retirement age in 2002 (retrospectively measured in 2007). The vertical line marks the threshold dividing the control and treatment groups. 
Figure 3 Expected retirement age one year after the reform (2007)

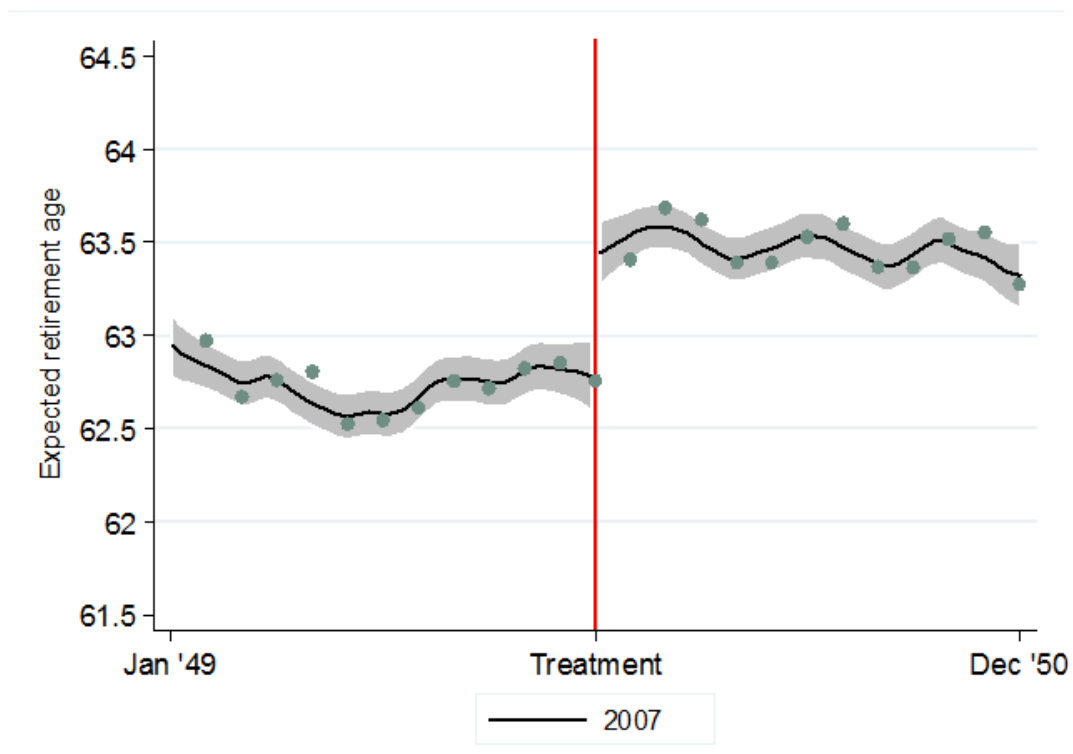

The figure presents the expected retirement age in 2007 (for two successive birth months). The vertical line marks the threshold dividing the control and treatment groups.

Figure 4 Additional pension wealth (2007)

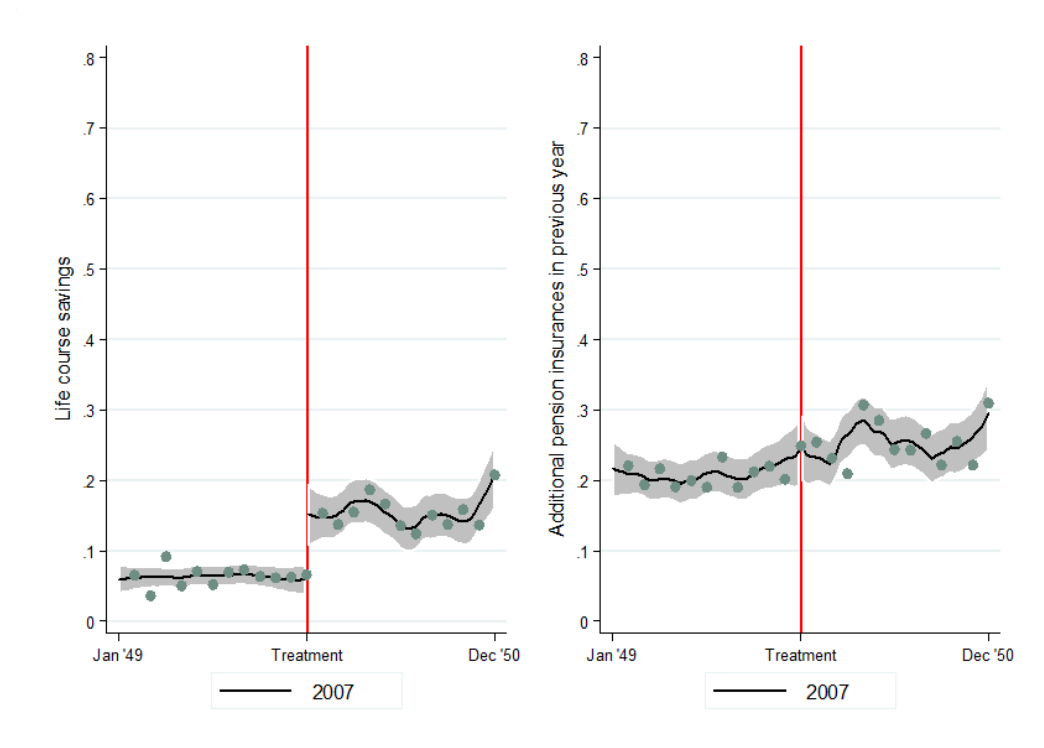

The figures present information on participation in the life course savings program and whether workers invested in additional pension insurance in the previous year (for two successive birth months). The vertical line marks the threshold dividing the control and treatment groups. 
Figure 5 Months earlier retirement due to Life course savings (2009)

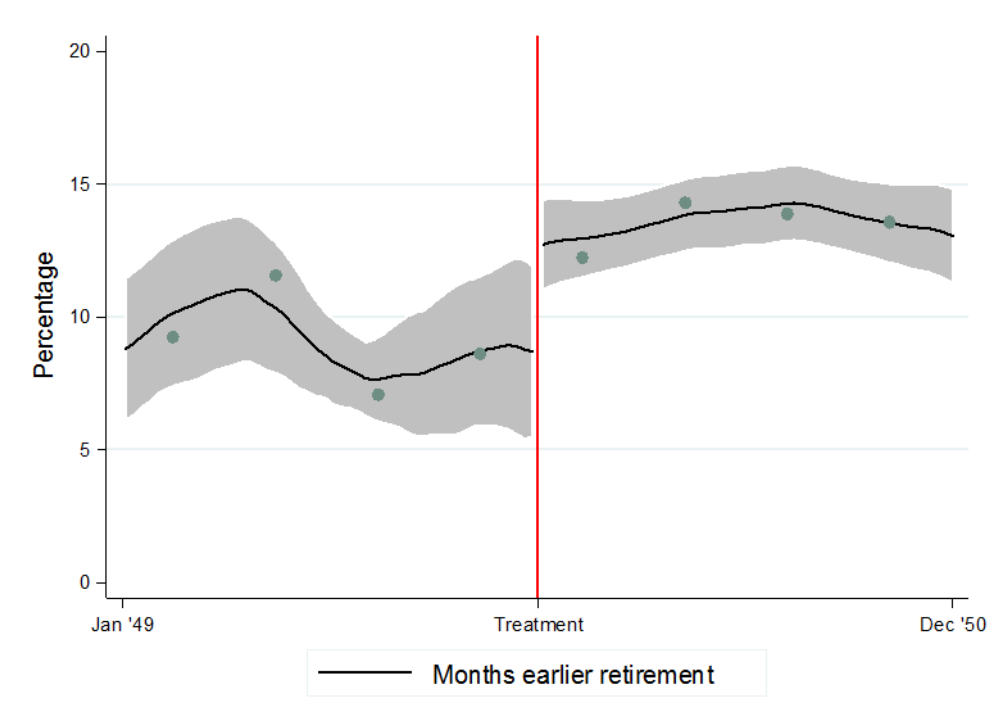

The figure presents the number of months that workers expect to save in the life course savings program (for two successive birth months). The vertical line marks the threshold dividing the control and treatment groups.

\section{Figure 6 Developments in expected age of retirement}
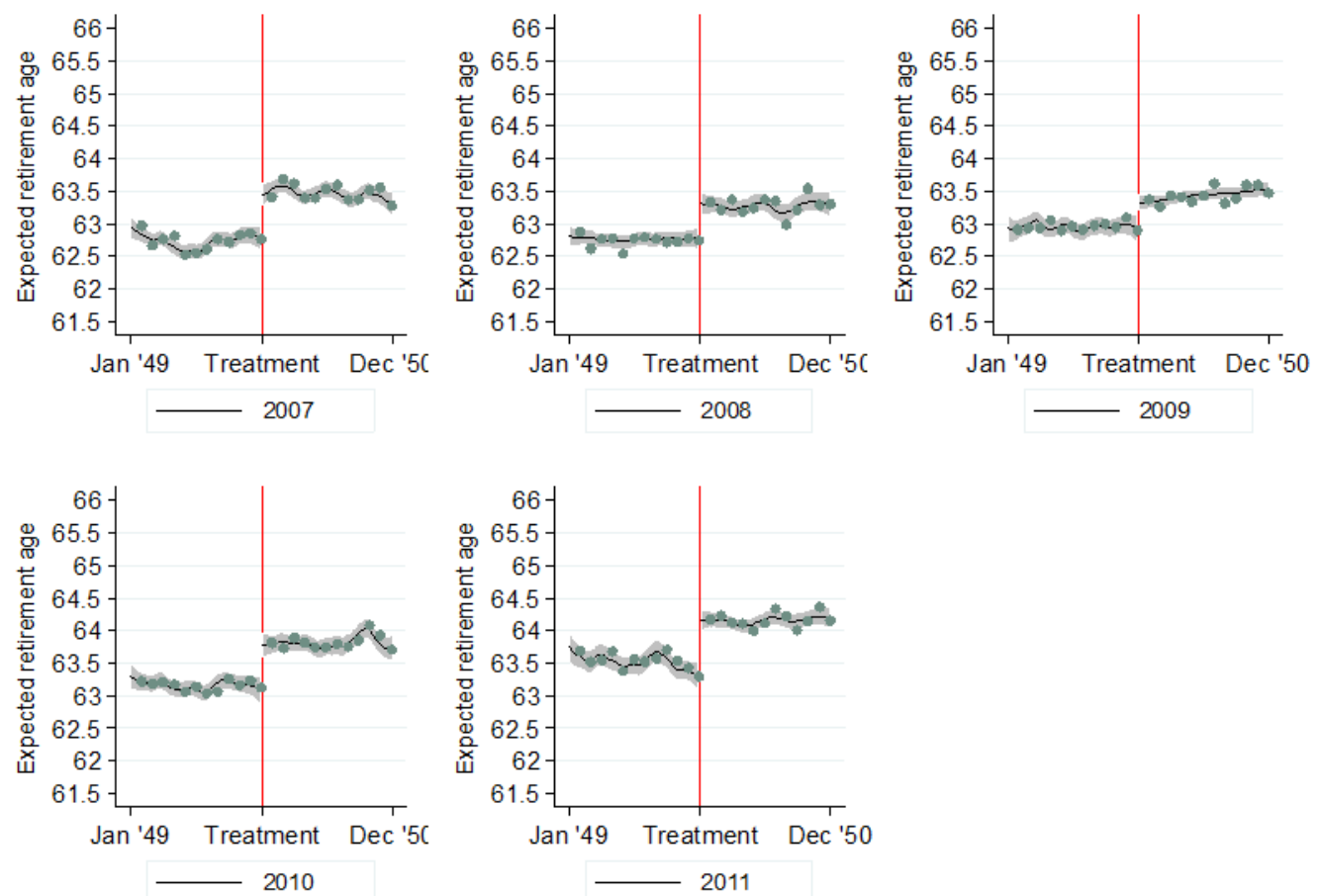

The figures present the expected retirement age for the period 2007-2011 (for two successive birth months). The vertical line marks the threshold dividing the control and treatment groups. 
Figure 7 Retirement realizations in 2014

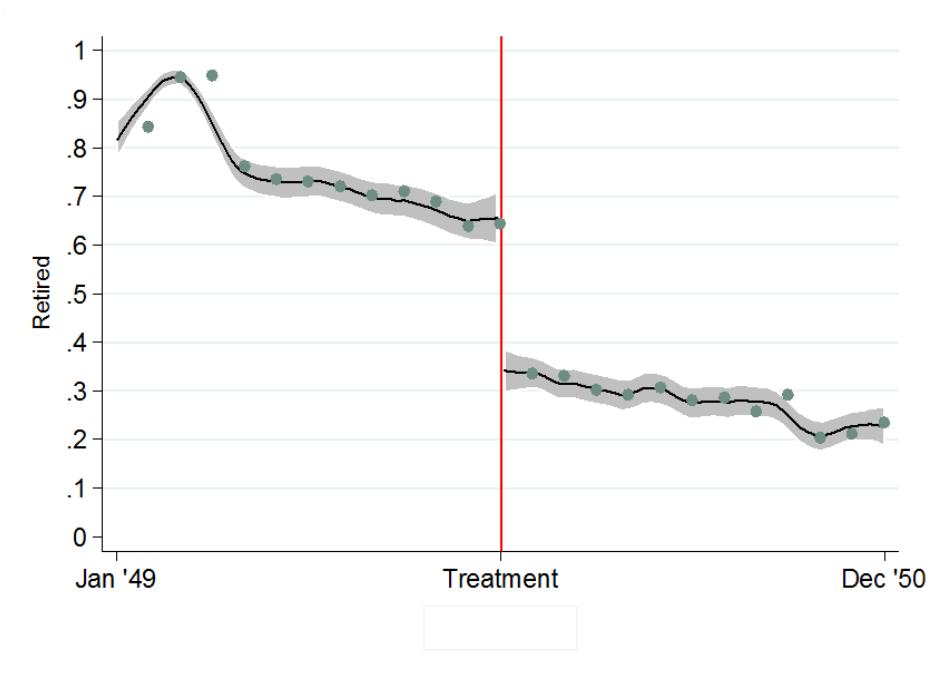

The figure presents the retirement rates in 2014(for two successive birth months). The vertical line marks the threshold dividing the control and treatment groups. 


\section{Appendix A}

\section{Figure A1 Expected pension benefits in the longer run}

The figures present the expected retirement benefits for the period 2007-2011 (for two successive birth months). The vertical line marks the threshold dividing the control and treatment groups.
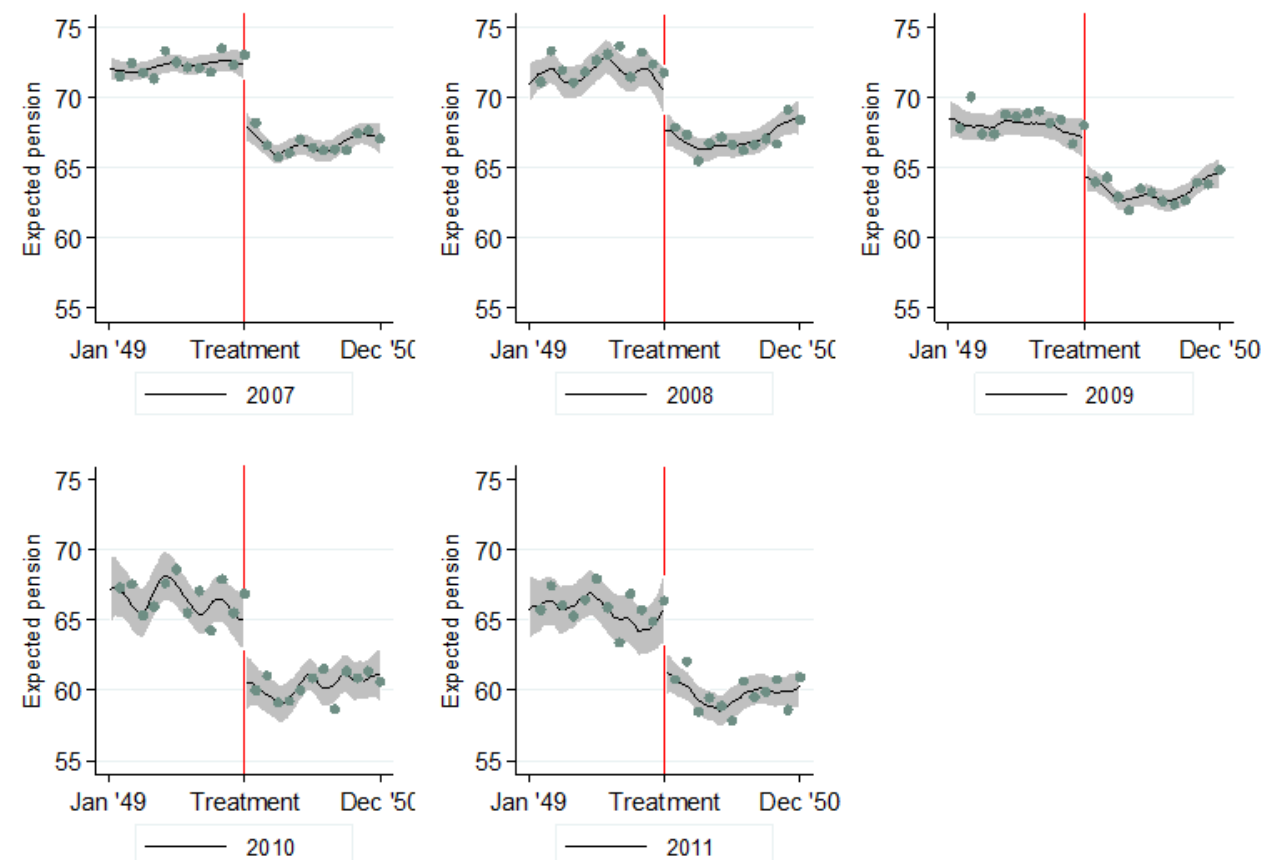
Table A1 Retirement expectations in 2002

\begin{tabular}{lcc}
\hline Expected retirement age in & $(1)$ & $(2)$ \\
2002 & -0.054 & -0.074 \\
\hline Treatment dummy & $(0.109)$ & $(0.106)$ \\
& -0.105 & -0.196 \\
Birth date /100 & $(0.258)$ & $(0.251)$ \\
& $1.530^{* *}$ & $1.337^{* *}$ \\
Birth date^2 & $(0.688)$ & $(0.669)$ \\
& & $-0.216^{* *}$ \\
Married & & $(0.106)$ \\
& & $-0.203^{*}$ \\
Low educated & & \\
(intermediate education is & & $(0.107)$ \\
ref) & & $0.280^{* * *}$ \\
& & $(0.094)$ \\
High educated & & $0.520^{* * *}$ \\
Wage (ln) & & $(0.137)$ \\
& & $-0.082^{* * *}$ \\
Number of contribution & & $(0.006)$ \\
years to the pension fund & & $58.313^{* * *}$ \\
& & $(1.466)$ \\
Constant & $61.398^{* * *}$ & 6564 \\
Number of observations & 6696 & 0.078 \\
Adjusted R-squared & 0.001 & \\
\hline
\end{tabular}

Standard errors in parentheses. Other control variables included: sector dummies. ${ }^{*} \mathrm{p}<0.10, * * \mathrm{p}<0.05$, $* * * \mathrm{p}<0.01$ 
Table A2 Longer run effects on the expected retirement age in 2007 before and after the reform: OLS results

\begin{tabular}{|c|c|c|c|c|c|}
\hline $\begin{array}{l}\text { Expected } \\
\text { retirement age } \\
\text { in } 2007\end{array}$ & $\begin{array}{c}(1) \\
2007\end{array}$ & $\begin{array}{c}(2) \\
2008\end{array}$ & $\begin{array}{c}(3) \\
2009\end{array}$ & $\begin{array}{c}(4) \\
2010\end{array}$ & $\begin{array}{c}(5) \\
2011\end{array}$ \\
\hline \multirow{2}{*}{$\begin{array}{l}\text { Treatment } \\
\text { dummy }\end{array}$} & $0.814^{* * *}$ & $0.530^{* * * *}$ & $0.436^{* * *}$ & $0.682^{* * *}$ & $0.726^{* * * *}$ \\
\hline & $(0.081)$ & $(0.100)$ & $(0.096)$ & $(0.092)$ & $(0.101)$ \\
\hline \multirow[t]{2}{*}{ Birth date / 1000} & -0.274 & -0.117 & 0.058 & -0.094 & -0.353 \\
\hline & $(0.192)$ & $(0.239)$ & $(0.231)$ & $(0.228)$ & $(0.247)$ \\
\hline \multirow{2}{*}{$\begin{array}{l}\text { Birthdate } \\
\text { squared }\end{array}$} & -0.242 & 0.101 & 0.231 & 0.459 & 0.815 \\
\hline & $(0.505)$ & $(0.629)$ & $(0.615)$ & $(0.617)$ & $(0.667)$ \\
\hline \multirow[t]{2}{*}{ Married } & 0.057 & -0.032 & -0.081 & -0.002 & -0.145 \\
\hline & $(0.079)$ & $(0.109)$ & $(0.099)$ & $(0.118)$ & $(0.112)$ \\
\hline \multirow[t]{2}{*}{ Low educated } & $-0.229^{* * *}$ & $-0.201^{* *}$ & -0.143 & 0.068 & 0.093 \\
\hline & $(0.077)$ & $(0.093)$ & $(0.095)$ & $(0.095)$ & $(0.126)$ \\
\hline \multirow[t]{2}{*}{ High educated } & 0.063 & -0.060 & -0.098 & -0.027 & -0.054 \\
\hline & $(0.068)$ & $(0.081)$ & $(0.083)$ & $(0.078)$ & $(0.078)$ \\
\hline \multirow[t]{2}{*}{ Wage (ln) } & 0.124 & 0.104 & $0.270^{* *}$ & $0.226^{*}$ & $0.441^{* * *}$ \\
\hline & $(0.103)$ & $(0.128)$ & $(0.131)$ & $(0.130)$ & $(0.135)$ \\
\hline \multirow{2}{*}{$\begin{array}{l}\text { Number of } \\
\text { contribution } \\
\text { years to the } \\
\text { pension fund }\end{array}$} & $-0.052^{* * *}$ & $-0.060^{* * * *}$ & $-0.046^{* * *}$ & $-0.047^{* * * *}$ & $-0.050^{* * *}$ \\
\hline & $(0.004)$ & $(0.006)$ & $(0.005)$ & $(0.005)$ & $(0.006)$ \\
\hline Constant & $\begin{array}{c}62.993^{* * *} \\
(1.099)\end{array}$ & $\begin{array}{c}63.787^{* * * *} \\
(1.382)\end{array}$ & $\begin{array}{c}61.875^{* * * *} \\
(1.414)\end{array}$ & $\begin{array}{c}62.412^{* * * *} \\
(1.414)\end{array}$ & $\begin{array}{c}60.716^{* * * *} \\
(1.494)\end{array}$ \\
\hline Observations & 6569 & 3446 & 3879 & 3259 & 2632 \\
\hline Adjusted $R^{2}$ & 0.093 & 0.092 & 0.072 & 0.109 & 0.131 \\
\hline
\end{tabular}




\section{Appendix B Sample attrition \\ Table B1 Number of individuals after selections}

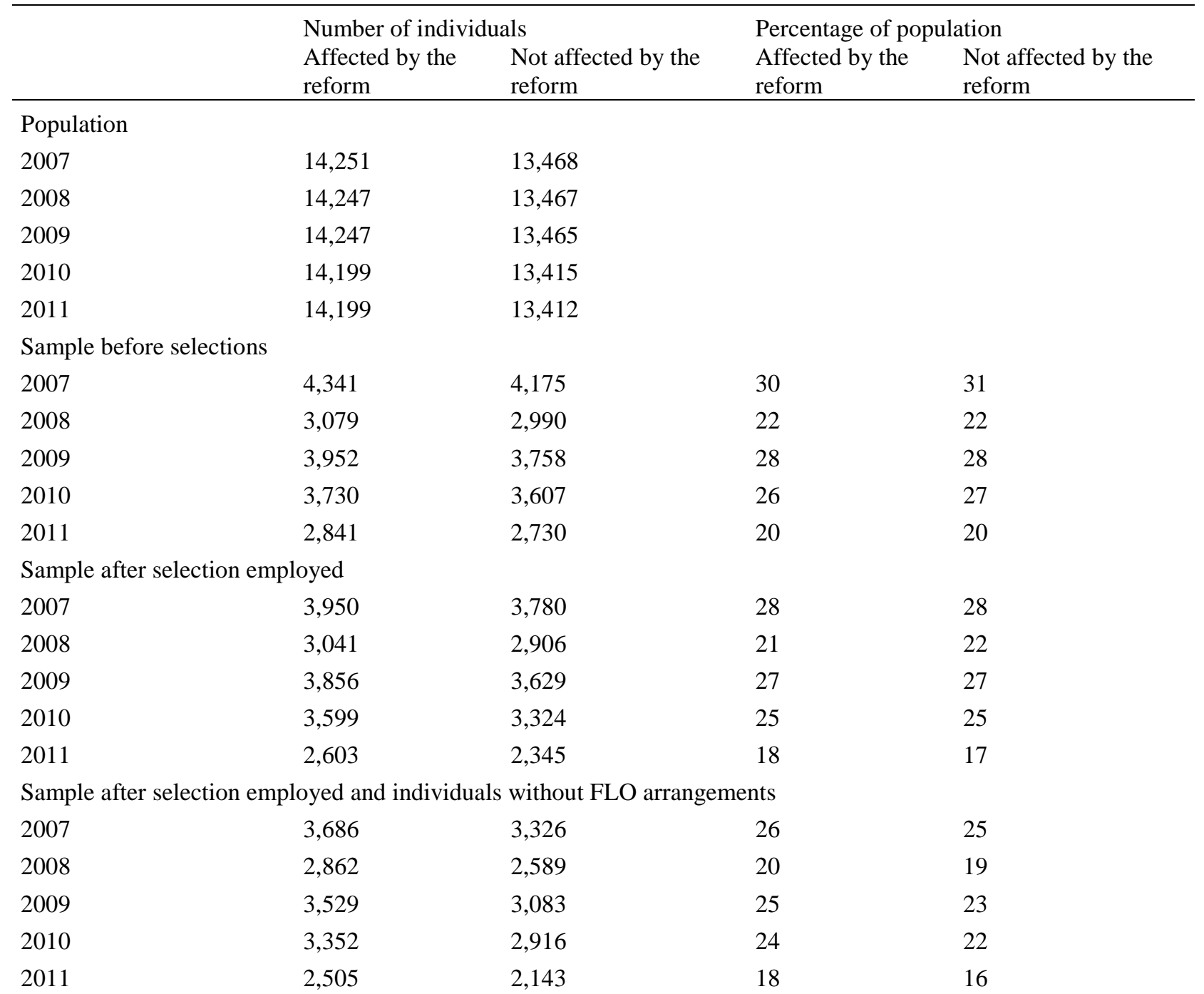

Sample after selection employed and individuals without FLO arrangements and without career breaks

$\begin{array}{lllll}2007 & 3,559 & 3,309 & 25 & 25 \\ 2008 & 2,770 & 2,577 & 19 & 19 \\ 2009 & 3,424 & 3,053 & 24 & 23 \\ 2010 & 3,256 & 2,882 & 23 & 21 \\ 2011 & 2,437 & 2,116 & 17 & 16\end{array}$

Sample after selection employed and individuals without FLO arrangements and without career breaks and expected retirement age is not missing

$\begin{array}{lllll}2007 & 3,468 & 3,234 & 24 & 24 \\ 2008 & 2,072 & 2,070 & 15 & 15 \\ 2009 & 3,196 & 2,888 & 22 & 21 \\ 2010 & 2,969 & 2,631 & 21 & 20 \\ 2011 & 2,173 & 1,847 & 15 & 14\end{array}$


Sample after selection employed and individuals without FLO arrangements and without career breaks and expected retirement age is not missing and conditional on presence in 2007

\begin{tabular}{lllll}
2007 & 3,468 & 3,234 & 24 & 24 \\
2008 & 1,864 & 1,863 & 13 & 14 \\
2009 & 2,054 & 1,864 & 14 & 14 \\
2010 & 1,946 & 1,719 & 14 & 13 \\
2011 & 1,453 & 1,232 & 10 & 9 \\
\hline
\end{tabular}

Table B2 OLS results: selection into the survey

\begin{tabular}{|c|c|c|c|c|c|}
\hline $\begin{array}{l}\text { Participation in the } \\
\text { survey }\end{array}$ & $\begin{array}{c}(1) \\
2007\end{array}$ & $\begin{array}{c}(2) \\
2008\end{array}$ & $\begin{array}{c}(3) \\
2009\end{array}$ & $\begin{array}{c}(4) \\
2010\end{array}$ & $\begin{array}{c}(5) \\
2011\end{array}$ \\
\hline \multirow{2}{*}{$\begin{array}{l}\text { Treated (affected by } \\
\text { the policy) }\end{array}$} & -0.005 & -0.006 & -0.002 & -0.006 & -0.003 \\
\hline & $(0.006)$ & $(0.005)$ & $(0.005)$ & $(0.005)$ & $(0.005)$ \\
\hline Constant & $\begin{array}{c}0.310 * * * \\
(0.004)\end{array}$ & $\begin{array}{c}0.222 * * * \\
(0.004)\end{array}$ & $\begin{array}{c}0.279 * * * \\
(0.004)\end{array}$ & $\begin{array}{c}0.269 * * * \\
(0.004)\end{array}$ & $\begin{array}{c}0.204 * * * \\
(0.003)\end{array}$ \\
\hline Observations & 27719 & 27714 & 27712 & 27614 & 27611 \\
\hline R-squared & -0.000 & 0.000 & -0.000 & 0.000 & -0.000 \\
\hline $\begin{array}{l}\text { Participation in the } \\
\text { survey (conditional } \\
\text { on response in 2007) }\end{array}$ & $\begin{array}{c}(1) \\
2007\end{array}$ & $\begin{array}{c}(2) \\
2008\end{array}$ & $\begin{array}{c}(3) \\
2009\end{array}$ & $\begin{array}{c}(4) \\
2010\end{array}$ & $\begin{array}{c}(5) \\
2011\end{array}$ \\
\hline \multirow{2}{*}{$\begin{array}{l}\text { Treated (affected by } \\
\text { the policy) }\end{array}$} & -0.005 & -0.004 & -0.001 & -0.003 & 0.000 \\
\hline & $(0.006)$ & $(0.005)$ & $(0.005)$ & $(0.005)$ & $(0.004)$ \\
\hline Constant & $\begin{array}{c}0.310 * * * \\
(0.004)\end{array}$ & $\begin{array}{c}0.200 * * * \\
(0.003)\end{array}$ & $\begin{array}{c}0.181 * * * \\
(0.003)\end{array}$ & $\begin{array}{c}0.177 * * * \\
(0.003)\end{array}$ & $\begin{array}{c}0.135 * * * \\
(0.003)\end{array}$ \\
\hline Observations & 27719 & 27714 & 27712 & 27614 & 27611 \\
\hline R-squared & -0.000 & -0.000 & -0.000 & -0.000 & -0.000 \\
\hline
\end{tabular}

Standard errors in parentheses. ${ }^{*} p<0.10,{ }^{* *} p<0.05,{ }^{* * *} p<0.01$ 
Table B3 Sample averages in 2007: People who stay in the survey in later years vs nonrespondents

\begin{tabular}{|c|c|c|c|c|c|c|}
\hline & $\begin{array}{l}\text { Affected by the } \\
\text { reform }\end{array}$ & $\begin{array}{l}\text { Not affected } \\
\text { by the reform }\end{array}$ & $\begin{array}{c}\mathrm{P}- \\
\text { value }\end{array}$ & $\begin{array}{l}\text { Affected by } \\
\text { the reform }\end{array}$ & $\begin{array}{l}\text { Not affected } \\
\text { by the reform }\end{array}$ & $\begin{array}{c}\mathrm{P}- \\
\text { value }\end{array}$ \\
\hline & \multicolumn{3}{|c|}{ Participated in later waves } & \multicolumn{3}{|c|}{ Non-respondents in later waves } \\
\hline \multicolumn{7}{|l|}{ Personal characteristics } \\
\hline Low education level & 0.121 & 0.104 & 0.289 & 0.143 & 0.136 & 0.680 \\
\hline High education level & 0.706 & 0.702 & 0.459 & 0.624 & 0.678 & 0.446 \\
\hline Married & 0.912 & 0.927 & 0.845 & 0.901 & 0.911 & 0.950 \\
\hline \multicolumn{7}{|l|}{ Job characteristics } \\
\hline Log of early wage income & 10.815 & 10.822 & 0.298 & 10.770 & 10.784 & 0.344 \\
\hline Number of contractual work hours & 0.996 & 0.997 & 0.750 & 0.996 & 0.995 & 0.994 \\
\hline \multicolumn{7}{|l|}{ Sectors } \\
\hline Government & 0.477 & 0.441 & 0.625 & 0.483 & 0.457 & 0.537 \\
\hline Education & 0.454 & 0.492 & 0.423 & 0.438 & 0.479 & 0.622 \\
\hline Privatized & 0.069 & 0.066 & 0.534 & 0.078 & 0.064 & 0.344 \\
\hline \multicolumn{7}{|l|}{$\begin{array}{l}\text { Alternative income and } \\
\text { savings }\end{array}$} \\
\hline Life course savings & 0.160 & 0.068 & 0.000 & 0.157 & 0.058 & 0.016 \\
\hline Extra pension savings in previous year & 0.251 & 0.212 & 0.339 & 0.271 & 0.219 & 0.079 \\
\hline Partner with own income & 0.744 & 0.727 & 0.219 & 0.745 & 0.736 & 0.427 \\
\hline Pension with own pension & 0.577 & 0.571 & 0.309 & 0.567 & 0.581 & 0.281 \\
\hline Positive net housing wealth & 0.709 & 0.686 & 0.069 & 0.672 & 0.691 & 0.600 \\
\hline Number of alternative wealth sources & 2.407 & 2.380 & 0.925 & 2.252 & 2.425 & 0.310 \\
\hline \multicolumn{7}{|l|}{ Retirement expectations } \\
\hline Expected retirement benefit & 66.631 & 71.656 & 0.000 & 67.674 & 72.765 & 0.000 \\
\hline Expected retirement age & 63.507 & 62.981 & 0.000 & 63.316 & 62.498 & 0.000 \\
\hline Expected retirement age before the reform & 61.387 & 61.685 & 0.617 & 61.197 & 61.241 & 0.081 \\
\hline
\end{tabular}


Table B4 Expected age of retirement in 2007 interacted with dummy for attrition in later years: OLS results

\begin{tabular}{lcc}
\hline & \multicolumn{2}{c}{ Expected Retirement Age 2007 } \\
\hline & $(1)$ & $(2)$ \\
\hline Treatment dummy & $0.724^{* * *}$ & $0.729 * * *$ \\
& $(0.098)$ & $(0.097)$ \\
Attrition & $-0.424 * * *$ & -1.848 \\
& $(0.101)$ & $(2.225)$ \\
Attrition * Treatment & 0.171 & 0.168 \\
& $(0.167)$ & $(0.166)$ \\
Birth date / 1000 & -0.298 & -0.370 \\
& $(0.243)$ & $(0.237)$ \\
Birthdate squared & 0.561 & 0.329 \\
& $(0.656)$ & $(0.642)$ \\
Married & & -0.004 \\
& & $(0.107)$ \\
Low educated & & $-0.243^{* *}$ \\
& & $(0.100)$ \\
High educated & & -0.001 \\
& & $(0.083)$ \\
Wage (ln) & & 0.041 \\
& & $(0.136)$ \\
Number of contribution years to the & & $-0.051^{* * *}$ \\
pension fund & & \\
& & $(0.006)$ \\
Constant & & $64.134 * * *$ \\
Observations & $(0.061)$ & $(1.451)$ \\
Adjusted $R^{2}$ & 6,702 & 6,569 \\
\hline
\end{tabular}

Standard errors in parentheses. Other control variables included: sector dummies.

$* \mathrm{p}<0.10, * * \mathrm{p}<0.05, * * * \mathrm{p}<0.01$ 